\title{
Current Knowledge on Correlations Between Highly Prevalent Dental Conditions and Chronic Diseases: An Umbrella Review
}

\author{
Max W. Seitz, MSc ${ }^{1}$; Stefan Listl, PhD, Dr Med Dent ${ }^{2,3}$; Andreas Bartols, Dr Med Dent ${ }^{4,5}$; \\ Ingrid Schubert, Dr Rer Soc ${ }^{6}$; Katja Blaschke, $\mathrm{MSc}^{6}$; Christian Haux, $\mathrm{MSc}^{1}$; \\ Marieke M. Van Der Zande, $\mathrm{PhD}^{2,3}$
}

\begin{abstract}
Accessible Version: www.cdc.gov/pcd/issues/2019/18_0641.htm
Suggested citation for this article: Seitz MW, Listl S, Bartols A, Schubert I, Blaschke K, Haux C, et al. Current Knowledge on Correlations Between Highly Prevalent Dental Conditions and Chronic Diseases: An Umbrella Review. Prev Chronic Dis 2019; 16:180641. DOI: https://doi.org/10.5888/pcd16.180641.
\end{abstract}

\section{PEER REVIEWED}

\section{Summary}

What is already known on this topic?

Substantive evidence supports a correlation between dental conditions and chronic systemic diseases.

What is added by this report?

We provide an overview of systematic reviews reporting on correlations between dental conditions and chronic diseases with an assessment of the evidence and extent of correlation.

What are the implications for public health practice?

There is a need for more awareness about 1) existing evidence on correlations between dental conditions and chronic systemic diseases, 2) potential opportunities for better medical-dental integration in the delivery of care, and 3) the need for future research about potentially causal links between dental conditions and chronic diseases.

\section{Abstract}

\section{Introduction}

Studies have investigated the relationships between chronic systemic and dental conditions, but it remains unclear how such knowledge can be used in clinical practice. In this article, we provide an overview of existing systematic reviews, identifying and evaluating the most frequently reported dental-chronic disease correlations and common risk factors.

\begin{abstract}
Methods
We conducted a systematic review of existing systematic reviews (umbrella review) published between 1995 and 2017 and indexed in 4 databases. We focused on the 3 most prevalent dental conditions and 10 chronic systemic diseases with the highest burden of disease in Germany. Two independent reviewers assessed all articles for eligibility and methodologic quality using the AMSTAR criteria and extracted data from the included studies.
\end{abstract}

\section{Results}

Of the initially identified 1,249 systematic reviews, 32 were included for qualitative synthesis. The dental condition with most frequently observed correlations to chronic systemic diseases was periodontitis. The chronic systemic disease with the most frequently observed correlations with a dental condition was type 2 diabetes mellitus (T2DM). Most dental-chronic disease correlations were found between periodontitis and T2DM and periodontitis and cardiovascular disease. Frequently reported common risk factors were smoking, age, sex, and overweight. Using the AMSTAR criteria, 2 studies were assessed as low quality, 26 studies as moderate quality, and 4 studies as high quality.

\section{Conclusion}

The quality of included systematic reviews was heterogeneous. The most frequently reported correlations were found for periodontitis with T2DM and for periodontitis with cardiovascular disease. However, the strength of evidence for these and other disease correlations is limited, and the evidence to assess the causality of these disease correlations remains unclear. Future research should focus on the causality of disease links in order to provide more decisive evidence with respect to the design of intersectoral care processes. 


\section{Introduction}

Human life expectancy has been increasing for many years (1). However, as life expectancy increases, so does the prevalence of chronic diseases within the population (2). Treatment of chronic diseases frequently takes place in highly specialized disciplines (3). However, chronic conditions often emerge, develop, and occur in parallel with other illnesses (4), and with each chronic condition life expectancy again decreases (5). Because of the high likelihood of patients with chronic conditions developing additional diseases, scientific study of the correlations between diseases is necessary.

The medical scope of such correlations often exceeds the boundaries of medical disciplines. An example of this is the correlation between dental conditions and other noncommunicable diseases, which have been investigated in many scientific publications and in previous empirical literature (6). In the past decades, however, dental care and primary medical care have largely evolved separately. Addressing the links between dental and other chronic conditions can improve health care and prevention of chronic conditions (7), in particular identifying appropriate and necessary areas for inter-professional cooperation between general medical and dental professionals (7).

Many systematic reviews (SRs) to estimate the extent of dental-chronic disease correlations have been conducted for specific dental conditions and chronic systemic diseases, but a systematic overview to provide information about the extent to which there is decisive evidence with respect to the design of intersectoral care processes does not exist so far. The aim of this study was to conduct an umbrella review to provide an overview of the most recent evidence from SRs about interdependencies between dental conditions and chronic systemic diseases. The underlying research question was, "What is the current state of knowledge concerning possible relationships between dental conditions and chronic systemic diseases?" The umbrella review aimed to identify potential intervention points for inter-professional cooperation, including evidence on 1) correlations between highly prevalent dental conditions and chronic systemic diseases, 2) common risk factors, and 3) how dental conditions cause chronic diseases and vice versa.

\section{Methods}

This study was conducted as part of a project aiming to improve intersectoral care between dentists and general practitioners (8). The results of this literature review will be combined with an analysis of claims data and patient reported measures into a decision support system (DSS). The DSS targets links between dental con- ditions and chronic systemic diseases managed in dental and primary care in Germany. The umbrella review focused on the chronic systemic diseases and dental conditions with the highest prevalence in Germany (9). The prevalence of these conditions in Germany is comparable to that of other Western European countries (10).

\section{Data sources}

The scope of the review was defined using the PICO structure (11). The target population was defined as patients with a combination of 1) a chronic systemic disease and 2) 1 of the 3 dental conditions with the highest burden of disease: periodontitis (International Classification of Diseases, 10th Revision [ICD-10] K05), dental caries (ICD-10: K02.0), and tooth loss (ICD-10: K08.1) $(12,13)$. There were no restrictions with respect to the type of (comparative) interventions or the (dental) health outcomes considered.

The search strategy was jointly developed by the authors (M.S., S.L., C.H., M.vdZ.) and sense-checked by 2 experts in dental and primary care and pharmacology. A librarian specializing in SRs reviewed the search strategy. For dental conditions the search terms were adjusted from the study by Haag et al (14).

The applied search strategy we used for PubMed is as follows:

\footnotetext{
(“Dental Caries" [Mesh] OR “Periodontal Diseases”[Mesh] OR “Mouth, Edentulous"[Mesh]

OR ((tooth[tiab] OR teeth[tiab] OR dental) AND (caries[tiab] OR carious[tiab] OR decay*[tiab] OR lesion*[tiab]))

OR “root caries"[tiab] OR “root decay"[tiab] OR “DMF Index"[tiab] OR “DMFT”[tiab] OR “DMFS”[tiab]

OR periodontal disease ${ }^{*}$ [tiab] OR periodontitis[tiab] OR periodontal pocket*[tiab] OR periodontology[tiab]

OR “periodontal therapy"[tiab] OR periodontal treatment*[tiab] OR “periodontics"[tiab] OR “tooth loss"[tiab]

OR “number of teeth" [tiab] OR "shortened dental arch" [tiab] OR "functional dentition"[tiab] OR edentul*[tiab]

OR “missing teeth"[tiab] OR “missing tooth"[tiab] OR prosthodontics[tiab])

AND (“Chronic Disease”[Mesh] OR “Disease Progression”[Mesh] OR “Cardiovascular Diseases"[Mesh]

OR “Diabetes Mellitus"[Mesh] OR “Lung Diseases, Obstructive”[Mesh] OR "Pneumonia”[Mesh]

OR “Arthritis, Rheumatoid”[Mesh] OR ((disease[tiab] OR diseases[tiab] OR condition[tiab]

OR illness[tiab] OR ill[tiab] OR diseased[tiab]) AND (chronic[tiab] OR chronically[tiab]

OR systemic[tiab] OR cardiovascular[tiab] OR cerebrovascular[tiab])) OR “diabetes mellitus"[tiab]
}

\footnotetext{
The opinions expressed by authors contributing to this journal do not necessarily reflect the opinions of the U.S. Department of Health and Human Services, the Public Health Service, the Centers for Disease Control and Prevention, or the authors' affiliated institutions.
} 
OR “glycemic control”[tiab] OR diabetes[tiab] OR hyperglycemia[tiab] OR stroke[tiab] OR “cerebral ischemia"[tiab]

OR bronchitis[tiab] OR “pulmonary disease"[tiab] OR pneumonia[tiab] OR

"rheumatoid arthritis"[tiab] OR Aspiration[tiab])

AND systematic[sb]

NOT (“animals"[Mesh] NOT “humans”[Mesh])

The search strategy was adapted for the searches in Embase, Cochrane, and LILACS. More details can be found here: https:// doi.org/10.11588/data/ORTPJN.

Because of the multiple existing definitions for periodontitis, the search strategy was developed liberally to include a broad definition of periodontal disease. In addition, chronic diseases were addressed under various definitions (15). We used the term to refer to the definition by the World Health Organization (WHO): "Noncommunicable diseases . . . also known as chronic diseases, are not passed from person to person. They are of long duration and generally slow progression" (16). To further refine the search and include results on specific chronic diseases, diabetes (ICD-10: E10-E14), cardiovascular disease (CVD) (ICD-10: I20-I25), and chronic respiratory diseases (ICD-10: J40-J47) were prioritized as highly prevalent chronic conditions (9). Additionally (in their initial and moderate phase), they can be primarily detected and comprehensively managed in primary care.

A comprehensive literature search was performed on the PubMed, Embase, Cochrane, and LILACS databases in October 2017, including articles published up to 2017. EndNote version X8.1 was used for reference management (Clarivate Analytics). Duplicate references were excluded before article assessment. Two reviewers (M.S. and M.vdZ.) screened the title and abstract of all articles independently, excluding all records that did not meet the inclusion criteria. Based on the results of title and abstract screening, the inclusion criteria for the full-text screening were extended for the 10 chronic systemic diseases with the highest burden of disease. Those were defined as diseases that cause the most combined death and disability in Germany (9): ischemic heart disease, low back and neck pain, sensory organ diseases, cerebrovascular disease, lung cancer, Alzheimer disease, skin diseases, diabetes, chronic obstructive pulmonary disease (COPD), and migraine. The full text for all remaining articles was retrieved where available. In a second round, the articles were assessed by full text, using the adapted inclusion and exclusion criteria. Differences in assessment were discussed by the 2 reviewers, and in case of disagreements, a third reviewer (S.L.) made the final decision to include or exclude the article. The data from the remaining full-text articles were then extracted and the quality of the articles assessed.

\section{Study selection}

After the database searches were conducted, all potential articles were aggregated in EndNote. The articles were screened by title and abstract for relevance. To ascertain interrater reliability, a calibration between the reviewers was conducted. The decision for inclusion or exclusion by both reviewers was compared for the first 100 screened articles and agreement was calculated by means of the Kappa value (17). Discrepancies were solved by an open discussion between the reviewers. If no consent could be reached, the third reviewer (S.L.) made the final decision.

Study inclusion criteria were 1) must be published in English; 2) must be an SR, a meta-analysis, or an umbrella review; 3) must be on patients with one of the predefined dental conditions (periodontitis, dental caries, or tooth loss) and a chronic systemic disease; and 4) must report on the link between the diseases. Studies were excluded if they 1) did not meet the inclusion criteria; 2) reported exclusively on children or animals; 3 ) did not report precisely the underlying search strategy; 4) contained no clear criteria for inclusion and exclusion of articles; 5) had not searched multiple databases; 6) did not include original studies; 7) reported on the same study as another included systematic review; 8) were included in another study that was already included; and 9) reported exclusively on a) a confounder and a dental condition but not a chronic systemic disease or b) a confounder and a chronic systemic disease but not a dental condition. The complete list of articles excluded in the full text screening, with reason for exclusion, can be found here: https://doi.org/10.11588/data/ORTPJN.

\section{Data extraction}

The data from the articles included for qualitative synthesis were independently extracted by the 2 reviewers by using a standardized data collection form. Quantitative synthesis was not possible, because the included systematic reviews reported on correlations between various combinations of diseases. The 2 reviewers independently assessed the methodologic quality of the identified studies using the AMSTAR 11-point checklist (18), a measurement tool for assessing the quality of reporting of systematic reviews. Studies were designated as low quality if they met 0 to 3 criteria, moderate quality if they met 4 to 7 criteria, and high quality if they met 8 to 10 criteria. Discrepancies were discussed between the reviewers until agreement was reached on all items (Table 1). After this, the remaining articles were assessed.

\section{Results}

The search strategy was applied on the literature databases PubMed, Embase, Cochrane, and LILACS. We initially identified 1,249 articles; 992 remained after duplicates were removed.

The opinions expressed by authors contributing to this journal do not necessarily reflect the opinions of the U.S. Department of Health and Human Services, the Public Health Service, the Centers for Disease Control and Prevention, or the authors' affiliated institutions. 
Based on ratings of the 100 first-screened articles, there was good interrater reliability between the 2 reviewers $(\kappa=0.74)$. During title and abstract screening, 725 articles were excluded. The remaining 267 articles were evaluated for eligibility in a full-text assessment, and 235 were excluded (Figure 1). Thirty-two studies met the inclusion criteria and were included in the qualitative synthesis (Table 2).

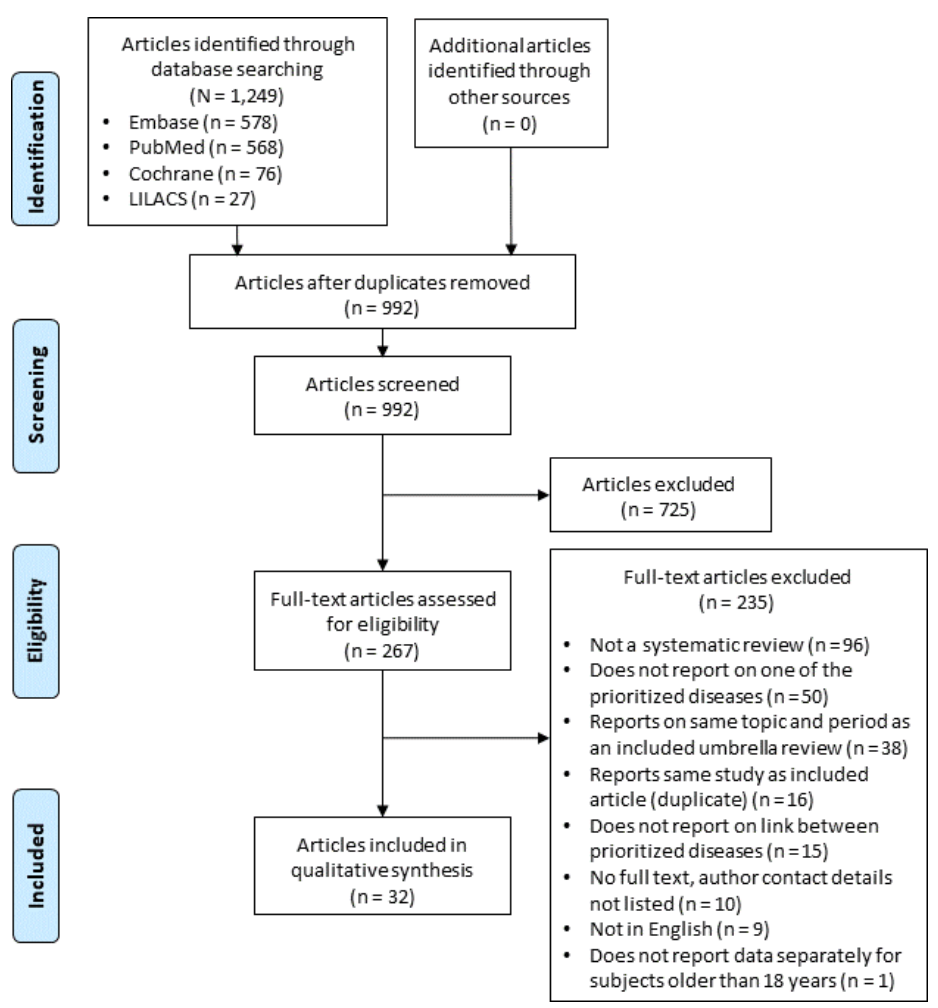

Figure 1. Flow diagram showing exclusion and inclusion process during the literature review based on the Preferred Reporting Items for Systematic Reviews and Meta-Analysis (PRISMA) system. Articles were screened for an umbrella review of systematic reviews published between 1995 and 2017 on correlation between prevalent dental conditions and chronic diseases in Germany.

\section{Methodologic quality of systematic reviews}

The quality of all SRs included in the qualitative synthesis was assessed using the 11-point AMSTAR checklist (Table 1). In our assessment, SRs met between 3 and 10 of the possible 11 criteria $($ median $=6)$. No review complied with all 11 points of the tool.

Criterion 3 ("Was a comprehensive literature search performed?" $[\mathrm{n}=32]$ ) and criterion 6 ("Were the characteristics of the included studies provided?" [n=31]) were met by nearly every SR. Criterion 11 ("Was the conflict of interest included?" $[\mathrm{n}=5]$ ) was rarely met. Criterion 7 ("Was the scientific quality of the included studies assessed and documented?" $[n=23])$ and criterion 10 ("Was the likelihood of publication bias assessed?" [n=12]) were fulfilled by many of the studies. Two studies were determined to be low quality, 26 studies were moderate quality, and 4 studies were high quality.

\section{Characteristics of included SRs}

The primary studies included in the SRs were conducted between 1995 (24) and May 2017 (21) (Table 2). The included SRs varied in diverse aspects. Multiple primary studies, including randomized controlled trials (RCTs) $(14,15)$, case-control studies (CCSs) $(22,23)$, cross-sectional studies $(22,23)$, cohort studies $(22)$, clinical trials (25), observational studies (32), mixed-method studies (32), pilot studies (41), and population surveys (41) were examined. The primary studies differed by study population, from 303 participants in an RCT (37) to $1,025,340$ subjects in a CCS (39). They also differed by location; studies were conducted in Europe (Austria, Belgium, France, Germany, Greece, Italy, Norway, Poland, Portugal, Spain, Sweden), North America (United States), South America (Brazil), and Asia (China, Iran, Japan, Saudi Arabia, South Korea, Taiwan).

Fifteen different disease combinations were examined in the included SRs (Table 3). Multiple studies reported on common risk factors that can have a progressive effect on dental and chronic systemic conditions. The most frequently mentioned were smoking $(21,23,35,36,39,41,43,44,46-48,50)$, age $(23,35,36,39,41,43,47)$, sex $(35,36,39,41,43)$, and body mass index (BMI) or overweight $(35,36,39,44,46)$.

In addition to reporting on common risk factors, multiple studies reported on chronic systemic diseases increasing the risk of developing a dental condition and vice versa. D'Aiuto et al (26) reported strong evidence for T2DM being a risk factor for periodontal diseases. Leng et al (36) reported that patients with a periodontal disease have a significantly increased risk for developing coronary heart disease, and patients with periodontitis have an elevated risk for myocardial infarction (47). Multiple studies reported on associations between cerebrovascular diseases (eg, stroke) and dental conditions. For example, Lafon et al (33) reported that the risk of ischemic or hemorrhagic stroke was higher for people with periodontitis (estimated adjusted risk, 1.63 [95\% confidence interval (CI),1.25-2.00]) and that tooth loss is a significant risk factor for stroke (estimated adjusted risk, 1.39 [95\% CI, 1.13-1.65]). Likewise, Leira et al (35) found that the risk of cerebral ischemia was higher in subjects with periodontitis (relative risk, 2.88 [95\% CI, 1.53-5.41]), suggesting a positive association between ischemic stroke and the prevalence of periodontitis. Another study reported that periodontal disease significantly increases the risk of COPD (49).

\footnotetext{
The opinions expressed by authors contributing to this journal do not necessarily reflect the opinions of the U.S. Department of Health and Human Services, the Public Health Service, the Centers for Disease Control and Prevention, or the authors' affiliated institutions.
} 


\section{Summary of the systematic reviews}

The studies included in the analysis reported on 107 correlations between dental conditions and chronic systemic diseases. Among the 32 SRs included in the qualitative synthesis, 6 were umbrella reviews. These 6 umbrella reviews incorporated 98 SRs, but 2 of the umbrella reviews investigated multiple disease correlations, not all of which met the inclusion criteria of this review. Therefore, in the analysis of disease correlations, 107 SRs were included.

The most frequently observed dental condition that was correlated with chronic systemic diseases was periodontitis $(n=88)$. Links between tooth loss and chronic systemic diseases $(\mathrm{n}=11)$ and dental caries with chronic systemic diseases $(n=8)$ were observed less often.

In terms of chronic systemic diseases, most correlations with dental conditions were identified for T2DM $(\mathrm{n}=51)$ and CVD $(\mathrm{n}=$ 41). Less frequently observed were correlations with cerebrovascular disease $(n=8)$, COPD $(n=3)$, dementia $(n=2)$, psoriasis $(n$ $=1)$, and lung cancer $(\mathrm{n}=1)$.

Most disease correlations were found for periodontitis with T2DM $(\mathrm{n}=46)(19-21,24,26,29,30,38,40)$ and periodontitis with CVD (n $=33)(23,27,28,31,34,36,37,39,41-44,47,48)$. This was followed by SRs indicating correlations of tooth loss with CVD $(n=6)(28)$, periodontitis with cerebrovascular disease $(\mathrm{n}=4)(25,28,32,35)$, and dental caries with T2DM $(n=4)(26)$. For the remaining diseases, between 0 and 2 correlations were observed.

The results of the data extraction showed that the included SRs indicated that there was an absence of causal evidence between the reported diseases. This was reported for correlations of CVD with periodontitis $(42,48)$ and cerebrovascular disease with dental caries (29). None of the included SRs, which reported on links between periodontitis and diabetes mellitus, reported to have specifically investigated about causal inference concerning the examined diseases (Figure 2).

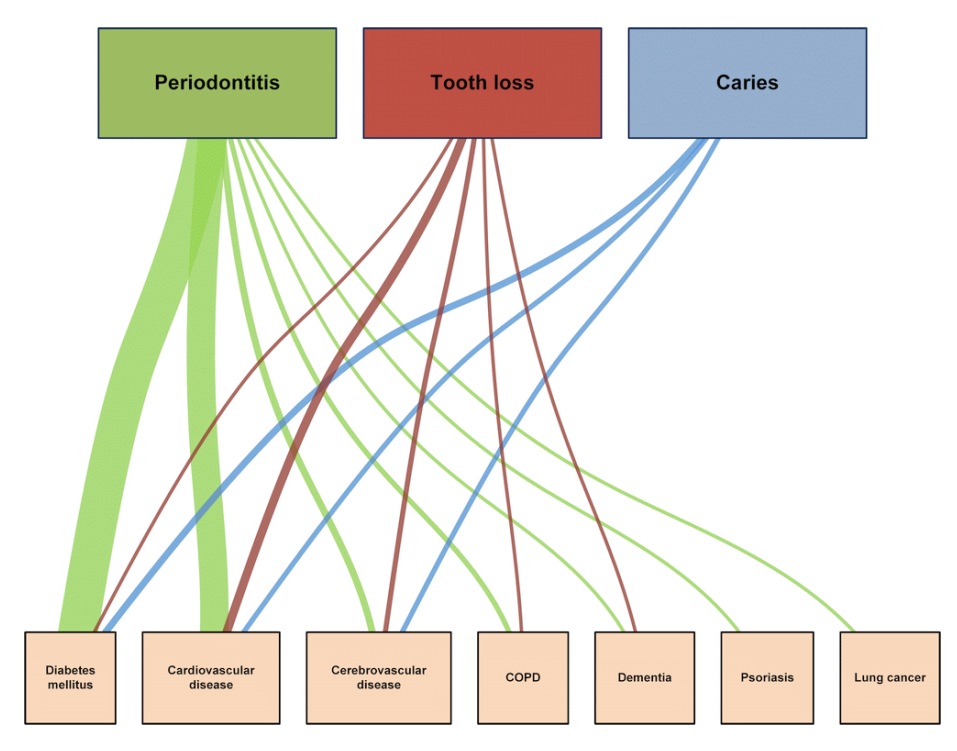

Figure 2. Illustration of the number of identified systematic reviews that showed disease correlations, umbrella review of systematic reviews published between 1995 and 2017 on correlation between prevalent dental conditions and chronic diseases in Germany. Width of lines illustrates the number of systematic reviews that report on the disease combinations. Abbreviation: COPD, chronic obstructive pulmonary disease.

\section{Discussion}

In our umbrella review, we found that of all the interrelationships between dental conditions and chronic systemic diseases described in the included systematic reviews, periodontitis was the dental condition with the most reported correlations to chronic systemic diseases and T2DM was the chronic condition for which most correlations to dental conditions were found. The most frequently reported correlations were 1) periodontitis with T2DM and 2) periodontitis with CVD.

The identified correlations should be carefully considered in the care provided to multimorbid patients with combinations of dental conditions and chronic systemic diseases. These patients may potentially benefit from an increased sensibility and awareness of practitioners for disease correlations, the potential for earlier diagnosis, and better coordination of the attending physicians. In this context, our findings can support practitioners by highlighting correlating diseases through common risk factors (eg, smoking) and disease indicators (eg, high hemoglobin A1c). For example, dentists treating patients with difficulties in controlling chronic periodontitis should consider the possibility of correlating chronic systemic conditions that worsen recovery and accelerate recurrence, such as T2DM. By coordinating the treatment with the attending physician or diabetes specialist, treatment and control of both correlating diseases can be improved. Better integration of diabetes

\footnotetext{
The opinions expressed by authors contributing to this journal do not necessarily reflect the opinions of the U.S. Department of Health and Human Services, the Public Health Service, the Centers for Disease Control and Prevention, or the authors' affiliated institutions.
} 
and periodontal care has also been highlighted in international medical guidelines $(52,53)$. Further improvement of intersectoral care necessitates that both dentist and general practitioner are sufficiently aware of existing correlations between dental conditions and chronic systemic diseases and how these correlations may influence treatments. For the treatment of diseases that are linked but treated by separate groups of health care professionals, communication, information exchange, and decision support can contribute to greater quality of care. At the same time, unnecessary medical interventions should be avoided if there is no solid evidence base supporting a possible benefit for the patient.

As for the correlation of periodontitis with T2DM, our findings indicate substantial evidence. In addition, the included studies suggest that the treatment of periodontitis may improve the glycemic regulation of T2DM patients $(19,20,24,26,29,30)$. Although the association between periodontitis and T2DM was most frequently studied among the included SRs, the SRs did not report to have specifically investigated about causal inference concerning the relationship between both diseases. Conversely, all SRs that investigated causality between dental conditions and other chronic diseases reported congruently about insufficient evidence to determine causality. As a result, we could not ultimately confirm that the identified relationships are causal.

For 2 disease correlations, periodontitis with T2DM and periodontitis with CVD, the existence of a correlation could be confirmed by multiple SRs. In case of other disease correlations (tooth loss with CVD, dental caries with DM, and periodontitis with cerebrovascular disease), evidence was present for only a few reviews $(n=4-6)$. There was evidence of a correlation for the remaining conditions, although it was limited $(n=1-2)$, and the existing evidence is still unclear. Regardless of the level of evidence for any of the correlations, the conclusiveness of currently existing evidence often remains vague. In some cases, studies contradicted or differed from each other with regard to the assessment.

When assessing potential causal pathways between dental conditions and chronic systemic diseases, common risk factors play an important role. They can have a direct or indirect impact on multiple disease entities. The SRs frequently reported common risk factors for dental and chronic systemic conditions, including smoking, age, sex, and BMI/overweight. A study by Sheiham and Watt (54) reported additionally about diet, hygiene, alcohol use, stress, and trauma as important common risk factors. Because common risk factors increase the possibility of further diseases in chronically ill patients, they can be used as indicators for the development or presence of another related disease. Raising health care practitioners' awareness of this issue may improve the prevention and early detection of comorbidities for chronically ill patients. In the context of intersectoral patient care, common risk factors should be considered to identify patients who should be referred to another specialist to verify a suspected comorbidity. Patients with comorbidities in particular could benefit from a better cooperation and coordination among the attending practitioners in various disciplines (7).

The study has several limitations. First, because of the heterogeneous quality of the included SRs, the evidence on links between chronic systemic and dental conditions should be interpreted with caution. However, to counteract the risk of bias by including heterogeneous and low-quality SRs, we assessed the quality of the reviews with the AMSTAR (18) tool, and the evaluation showed that the heterogeneity was moderate: 2 reviews were low quality, 26 were moderate quality, and 4 were high quality. In addition, the large number of included studies necessitated a more general overview than would be possible in a study focusing on specific diseases. However, this umbrella review was designed to summarize existing knowledge for links between dental conditions and chronic systemic diseases from a broad perspective. Because we used a broad search strategy, our search may not have identified studies using definitions that are not common in literature. In order not to miss any relevant SR or disease in spite of the broad search strategy, we included the most commonly used terms for each of the focused diseases, including key terms and categorizations used in each database. Medical terms that are often hidden under various classifications and definitions (eg, periodontitis [55]: chronic periodontitis, periodontosis, aggressive periodontitis, periodontal disease) were included, and the search was checked by 2 experts to ensure that all relevant terms were included.

Second, the included SRs documented various disease correlations, including different types of studies, populations, interventions, and outcomes. This, and differences in the research questions of the included SRs, restricted the comparability of our results. This showcases a high degree of heterogeneity in the literature on chronic-dental disease links. For example, numerous definitions and biomarkers for periodontitis have been used in the literature, and this may affect any overview of studies reporting on correlations between periodontal and chronic systemic diseases. Third, given the variety of chronic systemic diseases and the specific context for which this study was conducted, we prioritized chronic systemic diseases according to the prevalence of disease in Germany. Therefore, our findings may not be generalizable to other settings or contexts. We set this priority because the ultimate objective of this project (8) is to apply our findings to German routine care and to improve multimorbid patient care by general practitioners and dentists. But because the burden of disease in Germany is similar to that of other Western European countries (10) and because the consideration and treatment of patients with

The opinions expressed by authors contributing to this journal do not necessarily reflect the opinions of the U.S. Department of Health and Human Services, the Public Health Service, the Centers for Disease Control and Prevention, or the authors' affiliated institutions. 
dental conditions and general diseases is analogous worldwide, our findings are more broadly transferable.

Despite the limitations, to our knowledge our study is the first that provides a systematic and comprehensive overview and quality assessment of the evidence on correlations between highly prevalent dental conditions and chronic diseases, as reported in previously published SRs. Given the worldwide high prevalence and incidence of dental conditions and increasing co-occurrence with chronic systemic diseases, our findings are relevant and raise awareness for potential opportunities of better integrating medical and dental care.

\section{Future research direction}

The presented overview of correlations between dental conditions and chronic systemic diseases could be used as a guide to prioritize future studies on disease interdependencies, with particular attention being given to making causal inference. Focus should be set on the identification of the best-substantiated correlations and gaps in the study of disease correlations. To reduce uncertainties and to adequately raise awareness for disease correlations, it is important to provide health care practitioners and patients with information about the extent to which there is decisive evidence with respect to (potentially) causal disease links. For this purpose, clinical guidelines for intersectoral care could improve patient care. Yet, in the absence of robust and decisive evidence, guideline development continues to be highly challenging. In addition, even when guidelines can be developed, serious concerns have been raised about the persistence of "implementation gaps" $(7,56)$. To promote the development of intersectoral guidelines and provide practitioners with fundamental knowledge about disease correlations, research should focus on the underlying causes and extent of disease relationships. Furthermore, it should be assessed how and to what extent interventions can support the treatment and prevention of correlating diseases. Research into the causality underlying disease correlations is an important basis for guiding interdisciplinary collaboration and development of guidelines.

Not least, another promising opportunity to improve the translation from knowledge into action is the development of electronic decision support systems, such as the initiatives conducted by the Agency for Healthcare Research and Quality (57). Thereby, to promote joint considerations of practitioners who treat patients with comorbid conditions, it is also important to decipher the role of common risk factors, which may serve as early markers to initiate pathways of intersectoral care.

\section{Conclusion}

This review contributes to the literature by comprehensively summarizing the evidence, identifying and evaluating the most fre- quently reported disease correlations and common risk factors, and aggregating the information to provide information about the extent to which there is decisive evidence with respect to the design of intersectoral care processes. The most frequently reported correlations were found for periodontitis with diabetes mellitus type 2 and for periodontitis with cardiovascular disease. Associated common risk factors were smoking, age, sex and overweight. Correlations between dental and chronic systemic diseases have frequently been reported but the existing evidence remains unclear with respect to causal inference. Future research should therefore focus on the causality of disease links in order to provide more decisive evidence with respect to the design of intersectoral care processes. More decisive evidence would also be relevant for future prioritization in the design of intersectoral care processes and the development of electronic decision support systems.

\section{Acknowledgments}

Grant support for this project was provided by the Federal Joint Committee (G-BA) Innovation Fund, grant agreement no. $01 \mathrm{VSF} 16052$. This review was conducted as part of the Dent@Prevent project. Consortium members of the Dent@Prevent project have included Andreas Bartols, Joachim Bentz, Katja Blaschke, Joachim Fessler, Petra Knaup-Gregori, Christian Haux, Martin Hellmich, Olivier Kalmus, Stefan Listl, Bernt-Peter Robra, Christina Samel, Tanja Schamma, Ingrid Schubert, Max W. Seitz, Kirsten Smits, Jochen Walker, Winfried Walther, Marieke M. van der Zande. We thank all contributors to the Dent@Prevent project. No copyrighted materials/surveys/instruments/tools were used in our study.

M. W. Seitz and M. van der Zande contributed to conception, design, data acquisition, analysis, and interpretation, and drafted and critically revised the manuscript. A. Bartols, I. Schubert, K. Blaschke, and C. Haux contributed to design and interpretation and critically revised the manuscript. S. Listl contributed to conception, design, and interpretation and critically revised the manuscript. The authors declare that there are no conflicts of interest.

\section{Author Information}

Corresponding Author: Max W. Seitz, Institute of Medical Biometry and Informatics, University of Heidelberg, MarsiliusArkaden Turm West, Im Neuenheimer Feld 130.3, D-69120 Heidelberg, Germany. Telephone: 011-49-6221-56-7368. E-mail: max.seitz@med.uni-heidelberg.de.

Author Affiliations: ${ }^{1}$ University of Heidelberg, Institute of Medical Biometry and Informatics, Heidelberg, Germany.

The opinions expressed by authors contributing to this journal do not necessarily reflect the opinions of the U.S. Department of Health and Human Services, the Public Health Service, the Centers for Disease Control and Prevention, or the authors' affiliated institutions. 
${ }^{2}$ Section for Translational Health Economics, Department of Conservative Dentistry, Heidelberg University, Heidelberg, Germany. ${ }^{3}$ Radboud University Medical Center, Radboud Institute for Health Sciences, Department of Dentistry - Quality and Safety of Oral Healthcare, Nijmegen, The Netherlands. ${ }^{4}$ Dental Academy for Continuing Professional Development, Karlsruhe, Germany. ${ }^{5}$ Christian-Albrechts-University Kiel, Clinic for Conservative Dentistry and Periodontology, Kiel, Germany. ${ }^{6} \mathrm{PMV}$ Research Group, Faculty of Medicine and University Hospital Cologne, University of Cologne, Cologne, Germany.

\section{References}

1. Wang H, Naghavi M, Allen C, Barber RM, Bhutta ZA, Carter A, et al.; GBD 2015 Mortality and Causes of Death Collaborators. Global, regional, and national life expectancy, all-cause mortality, and cause-specific mortality for 249 causes of death, 1980-2015: a systematic analysis for the Global Burden of Disease Study 2015. Lancet 2016; 388(10053):1459-544.

2. Salomon JA, Wang H, Freeman MK, Vos T, Flaxman AD, Lopez AD, et al. Healthy life expectancy for 187 countries, 1990-2010: a systematic analysis for the Global Burden Disease Study 2010. Lancet 2012;380(9859):2144-62.

3. Wagner EH, Austin BT, Von Korff M. Organizing care for patients with chronic illness. Milbank Q 1996;74(4):511-44.

4. van den Akker M, Buntinx F, Metsemakers JF, Roos S, Knottnerus JA. Multimorbidity in general practice: prevalence, incidence, and determinants of co-occurring chronic and recurrent diseases. J Clin Epidemiol 1998;51(5):367-75.

5. DuGoff EH, Canudas-Romo V, Buttorff C, Leff B, Anderson GF. Multiple chronic conditions and life expectancy: a life table analysis. Med Care 2014;52(8):688-94.

6. Linden GJ, Lyons A, Scannapieco FA. Periodontal systemic associations: review of the evidence. J Clin Periodontol 2013; 40(Suppl 14):S8-19.

7. Petersen PE. The World Oral Health Report 2003: continuous improvement of oral health in the 21 st century - the approach of the WHO Global Oral Health Programme. Community Dent Oral Epidemiol 2003;31(Suppl 1):3-23.

8. Haux C, Listl S, Ganzinger M, Schubert I, Knaup P. Towards an evidence-informed and patient centered decision support system for intersectoral care; 2017.

9. Institute for Health Metrics and Evaluation. Global burden of disease; 2016. http://www.healthdata.org/germany. Accessed February 10, 2018.
10. Plass D, Vos T, Hornberg C, Scheidt-Nave C, Zeeb H, Krämer A. Trends in disease burden in Germany: results, implications and limitations of the Global Burden of Disease study. Dtsch Arztebl Int 2014;111(38):629-38.

11. Schardt C, Adams MB, Owens T, Keitz S, Fontelo P. Utilization of the PICO framework to improve searching PubMed for clinical questions. BMC Med Inform Decis Mak 2007;7(1):16.

12. Marcenes W, Kassebaum NJ, Bernabé E, Flaxman A, Naghavi M, Lopez A, et al. Global burden of oral conditions in 19902010: a systematic analysis. J Dent Res 2013;92(7):592-7.

13. Petersen PE, Ogawa H. The global burden of periodontal disease: towards integration with chronic disease prevention and control. Periodontol 2000 2012;60(1):15-39.

14. Haag DG, Peres KG, Balasubramanian M, Brennan DS. Oral conditions and health-related quality of life: a systematic review. J Dent Res 2017;96(8):864-74.

15. Bernell S, Howard SW. Use your words carefully: what is a chronic disease? Front Public Health 2016;4:159.

16. World Health Organization. Noncommunicable diseases; 2016. http://www.who.int/topics/noncommunicable_diseases/en/. Accessed January20, 2018.

17. McHugh ML. Interrater reliability: the kappa statistic. Biochem Med (Zagreb) 2012;22(3):276-82.

18. Shea BJ, Grimshaw JM, Wells GA, Boers M, Andersson N, Hamel C, et al. Development of AMSTAR: a measurement tool to assess the methodological quality of systematic reviews. BMC Med Res Methodol 2007;7(1):10.

19. Abduljabbar T, Javed F, Shah A, Samer MS, Vohra F, Akram $Z$. Role of lasers as an adjunct to scaling and root planing in patients with type 2 diabetes mellitus: a systematic review. Lasers Med Sci 2017;32(2):449-59.

20. Abduljabbar T, Vohra F, Javed F, Akram Z. Antimicrobial photodynamic therapy adjuvant to non-surgical periodontal therapy in patients with diabetes mellitus: a meta-analysis. Photodiagn Photodyn Ther 2017;17:138-46.

21. Al-Hamoudi N. Is antimicrobial photodynamic therapy an effective treatment for chronic periodontitis in diabetes mellitus and cigarette smokers: a systematic review and metaanalysis. Photodiagn Photodyn Ther 2017;19:375-82.

22. Azarpazhooh A, Leake JL. Systematic review of the association between respiratory diseases and oral health. J Periodontol 2006;77(9):1465-82.

23. Batista RM, Zandonade E, Roelke LH, Emmerich AO, Rosetti EP, Molina MC, et al. Association between periodontal disease and subclinic atherosclerosis: a systematic review. [Associacao entre doenca periodontal e aterosclerose subclinica: Uma revisao sistematica.]. J Vasc Bras 2011;10(3):229-38.

\footnotetext{
The opinions expressed by authors contributing to this journal do not necessarily reflect the opinions of the U.S. Department of Health and Human Services, the Public Health Service, the Centers for Disease Control and Prevention, or the authors' affiliated institutions.
} 
24. Botero JE, Rodríguez C, Agudelo-Suarez AA. Periodontal treatment and glycemic control in patients with diabetes and periodontitis: an umbrella review. Aust Dent J 2016; 61(2):134-48.

25. Dai R, Lam OL, Lo EC, Li LS, Wen Y, McGrath C. A systematic review and meta-analysis of clinical, microbiological, and behavioural aspects of oral health among patients with stroke. J Dent 2015;43(2):171-80.

26. D'Aiuto F, Gable D, Syed Z, Allen Y, Wanyonyi KL, White S, et al. Evidence summary: the relationship between oral diseases and diabetes. Br Dent J 2017;222(12):944-8.

27. D'Aiuto F, Orlandi M, Gunsolley JC. Evidence that periodontal treatment improves biomarkers and CVD outcomes. J Periodontol 2013;84(4Suppl):S85-105.

28. Dietrich T, Webb I, Stenhouse L, Pattni A, Ready D, Wanyonyi KL, et al. Evidence summary: the relationship between oral and cardiovascular disease. Br Dent J 2017; 222(5):381-5.

29. Faggion CM Jr, Cullinan MP, Atieh M. An overview of systematic reviews on the effectiveness of periodontal treatment to improve glycemic control. J Periodontal Res 2016; 51(6):716-25.

30. Hasuike A, Iguchi S, Suzuki D, Kawano E, Sato S. Systematic review and assessment of systematic reviews examining the effect of periodontal treatment on glycemic control in patients with diabetes. Med Oral Patol Oral Cir Bucal 2017; 22(2):e167-76.

31. Kelly JT, Avila-Ortiz G, Allareddy V, Johnson GK, Elangovan $\mathrm{S}$. The association between periodontitis and coronary heart disease: a quality assessment of systematic reviews. J Am Dent Assoc 2013;144(4):371-9.

32. Kothari M, Pillai RS, Kothari SF, Spin-Neto R, Kumar A, Nielsen JF. Oral health status in patients with acquired brain injury: a systematic review. Oral Surg Oral Med Oral Pathol Oral Radiol 2017;123(2):205-219.e207.

33. Lafon A, Pereira B, Dufour T, Rigouby V, Giroud M, Béjot Y, et al. Periodontal disease and stroke: a meta-analysis of cohort studies. Eur J Neurol 2014;21(9):1155-61, e66-7.

34. Lam OLT, Zhang W, Samaranayake LP, Li LSW, McGrath C. A systematic review of the effectiveness of oral health promotion activities among patients with cardiovascular disease. Int J Cardiol 2011;151(3):261-7.

35. Leira Y, Seoane J, Blanco M, Rodríguez-Yáñez M, Takkouche B, Blanco J, et al. Association between periodontitis and ischemic stroke: a systematic review and meta-analysis. Eur J Epidemiol 2017;32(1):43-53.

36. Leng WD, Zeng XT, Kwong JSW, Hua XP. Periodontal disease and risk of coronary heart disease: an updated metaanalysis of prospective cohort studies. Int J Cardiol 2015; 201:469-72.
37. Li C, Lv Z, Shi Z, Zhu Y, Wu Y, Li L, et al. Periodontal therapy for the management of cardiovascular disease in patients with chronic periodontitis. Cochrane Database Syst Rev 2014;(8):CD009197.

38. Lira R, Santos CM, Oliveira BH, Fischer RG, Santos A. Effects on HbA1c in diabetic patients of adjunctive use of systemic antibiotics in nonsurgical periodontal treatment: a systematic review. J Dent 2017;66:1-7.

39. Martin-Cabezas R, Seelam N, Petit C, Agossa K, Gaertner S, Tenenbaum $\mathrm{H}$, et al. Association between periodontitis and arterial hypertension: a systematic review and meta-analysis. Am Heart J 2016;180:98-112.

40. Mauri-Obradors E, Estrugo-Devesa A, Jané-Salas E, Viñas M, López-López J. Oral manifestations of Diabetes Mellitus. A systematic review. Med Oral Patol Oral Cir Bucal 2017; 22(5):e586-94.

41. Orlandi M, Suvan J, Petrie A, Donos N, Masi S, Hingorani A, et al. Association between periodontal disease and its treatment, flow-mediated dilatation and carotid intima-media thickness: a systematic review and meta-analysis. Atherosclerosis 2014;236(1):39-46.

42. Sanchez P, Everett B, Salamonson Y, Ajwani S, George A. Oral healthcare and cardiovascular disease: a scoping review of current strategies and implications for nurses. J Cardiovasc Nurs 2017;32(3):E10-20.

43. Schmitt A, Carra MC, Boutouyrie P, Bouchard P. Periodontitis and arterial stiffness: a systematic review and meta-analysis. J Clin Periodontol 2015;42(11):977-87.

44. Teeuw WJ, Slot DE, Susanto H, Gerdes VE, Abbas F, D’Aiuto $\mathrm{F}$, et al. Treatment of periodontitis improves the atherosclerotic profile: a systematic review and meta-analysis. J Clin Periodontol 2014;41(1):70-9.

45. Tonsekar PP, Jiang SS, Yue G. Periodontal disease, tooth loss and dementia: Is there a link? A systematic review. Gerodontology 2017;34(2):151-63.

46. Ungprasert P, Wijarnpreecha K, Wetter DA. Periodontitis and risk of psoriasis: a systematic review and meta-analysis. J Eur Acad Dermatol Venereol 2017;31(5):857-62.

47. Xu S, Song M, Xiong Y, Liu X, He Y, Qin Z. The association between periodontal disease and the risk of myocardial infarction: a pooled analysis of observational studies. BMC Cardiovasc Disord 2017;17(1):50.

48. Zeng XT, Leng WD, Lam YY, Yan BP, Wei XM, Weng H, et al.. Periodontal disease and carotid atherosclerosis: a metaanalysis of 17,330 participants. Int J Cardiol 2016; 203:1044-51.

49.Zeng XT, Tu ML, Liu DY, Zheng D, Zhang J, Leng W. Periodontal disease and risk of chronic obstructive pulmonary disease: a meta-analysis of observational studies. PLoS One 2012;7(10):e46508.

The opinions expressed by authors contributing to this journal do not necessarily reflect the opinions of the U.S. Department of Health and Human Services, the Public Health Service, the Centers for Disease Control and Prevention, or the authors' affiliated institutions. 
50.Zeng XT, Xia LY, Zhang YG, Li S, Leng WD, Kwong JS. Periodontal disease and incident lung cancer risk: a metaanalysis of cohort studies. J Periodontol 2016;87(10):1158-64.

51. Glenny AM, Esposito M, Coulthard P, Worthington HV. The assessment of systematic reviews in dentistry. Eur J Oral Sci 2003;111(2):85-92.

52. IDF Clinical Guidelines Task Force. IDF Guideline on oral health for people with diabetes. Brussels: International Diabetes Federation; 2009.

53. Sanz M, Ceriello A, Buysschaert M, Chapple I, Demmer RT, Graziani F, et al. Scientific evidence on the links between periodontal diseases and diabetes: consensus report and guidelines of the joint workshop on periodontal diseases and diabetes by the International diabetes Federation and the European Federation of Periodontology. Diabetes Res Clin Pract 2018;137:231-41.

54. Sheiham A, Watt RG. The common risk factor approach: a rational basis for promoting oral health. Community Dent Oral Epidemiol 2000;28(6):399-406.

55. Savage A, Eaton KA, Moles DR, Needleman I. A systematic review of definitions of periodontitis and methods that have been used to identify this disease. J Clin Periodontol 2009; 36(6):458-67.

56. Sippli K, Rieger MA, Huettig F. GPs' and dentists' experiences and expectations of interprofessional collaboration: findings from a qualitative study in Germany. BMC Health Serv Res 2017;17(1):179.

57. Agency for Healthcare Research and Quality. Advancing excellence in health care. Global burden of disease; 2018. https://cds.ahrq.gov/. Accessed May 14, 2018.

The opinions expressed by authors contributing to this journal do not necessarily reflect the opinions of the U.S. Department of Health and Human Services, the Public Health Service, the Centers for Disease Control and Prevention, or the authors' affiliated institutions. 


\section{Tables}

Table 1. Results of the Quality Assessment for Included Systematic Reviews Using AMSTAR Checklist, Systematic Umbrella Review of Correlation Between Prevalent Dental Conditions and Chronic Diseases, 1995-2017

\begin{tabular}{|c|c|c|c|c|c|c|c|c|c|c|c|c|}
\hline Study (year) & $\begin{array}{c}\text { 1. A } \\
\text { Priori } \\
\text { Design }\end{array}$ & $\begin{array}{l}\text { 2. Du- } \\
\text { plicate } \\
\text { Selec- } \\
\text { tion }\end{array}$ & $\begin{array}{l}\text { 3. Literat- } \\
\text { ure } \\
\text { Search }\end{array}$ & $\begin{array}{l}\text { 4. Status } \\
\text { of Publica- } \\
\text { tion }\end{array}$ & $\begin{array}{l}\text { 5. List } \\
\text { of } \\
\text { Stud- } \\
\text { ies }\end{array}$ & $\begin{array}{l}\text { 6. Charac- } \\
\text { teristics of } \\
\text { Studies }\end{array}$ & $\begin{array}{l}\text { 7. Qual- } \\
\text { ity of } \\
\text { Studies }\end{array}$ & $\begin{array}{l}\text { 8. Sci- } \\
\text { entific } \\
\text { Quality }\end{array}$ & $\begin{array}{l}\text { 9. Appropri- } \\
\text { ate Meth- } \\
\text { ods }\end{array}$ & $\begin{array}{l}\text { 10. Likeli- } \\
\text { hood of } \\
\text { Bias }\end{array}$ & $\begin{array}{l}\text { 11. Con- } \\
\text { flict of In- } \\
\text { terest }\end{array}$ & Score \\
\hline $\begin{array}{l}\text { Abduljabbar, Javed et al } \\
(2017)(19)\end{array}$ & 0 & 1 & 1 & 0 & 1 & 1 & 1 & 1 & 1 & 0 & 0 & 7 \\
\hline $\begin{array}{l}\text { Abduljabbar, Vohra et al } \\
(2017)(20)\end{array}$ & 1 & 1 & 1 & 1 & 1 & 1 & 1 & 1 & 1 & 0 & 0 & 9 \\
\hline Al-Hamoudi (2017) (21) & 0 & 0 & 1 & 0 & 0 & 1 & 1 & 0 & 1 & 0 & 0 & 4 \\
\hline $\begin{array}{l}\text { Azarpazhooh and Leake } \\
(2006)(22)\end{array}$ & 0 & 0 & 1 & 0 & 1 & 1 & 1 & 0 & 0 & 0 & 0 & 4 \\
\hline Batista et al (2011) (23) & 0 & 0 & 1 & 1 & 1 & 1 & 0 & 0 & 0 & 0 & 0 & 4 \\
\hline Botero et al (2016) (24) & 1 & 1 & 1 & 1 & 0 & 1 & 1 & 1 & 1 & 1 & 0 & 9 \\
\hline Dai et al (2015) (25) & 0 & 1 & 1 & 0 & 1 & 1 & 1 & 0 & 1 & 1 & 0 & 7 \\
\hline D'Aiuto et al (2017) (26) & 0 & 1 & 1 & 0 & 0 & 1 & 0 & 0 & 1 & 0 & 0 & 4 \\
\hline D'Aiuto et al (2013) (27) & 0 & 1 & 1 & 0 & 0 & 1 & 1 & 0 & 0 & 0 & 1 & 5 \\
\hline Dietrich et al (2017) (28) & 0 & 0 & 1 & 0 & 0 & 1 & 1 & 0 & 0 & 0 & 0 & 3 \\
\hline Faggion et al (2016) (29) & 0 & 1 & 1 & 0 & 1 & 1 & 1 & 1 & 1 & 1 & 1 & 9 \\
\hline Hasuike et al (2017) (30) & 1 & 0 & 1 & 0 & 0 & 1 & 1 & 1 & 1 & 0 & 1 & 7 \\
\hline Kelly et al (2013) (31) & 0 & 1 & 1 & 0 & 1 & 0 & 1 & 1 & 1 & 0 & 1 & 7 \\
\hline Kothari et al (2017) (32) & 0 & 1 & 1 & 1 & 0 & 1 & 0 & 0 & 1 & 0 & 0 & 5 \\
\hline Lafon et al (2014) (33) & 0 & 1 & 1 & 0 & 0 & 1 & 1 & 0 & 1 & 0 & 0 & 5 \\
\hline Lam et al (2011) (34) & 0 & 1 & 1 & 0 & 0 & 1 & 0 & 0 & 0 & 0 & 0 & 3 \\
\hline Leira et al (2017) (35) & 1 & 1 & 1 & 0 & 0 & 1 & 1 & 1 & 1 & 0 & 0 & 7 \\
\hline Leng et al (2015) (36) & 1 & 0 & 1 & 0 & 0 & 1 & 0 & 0 & 1 & 1 & 0 & 5 \\
\hline Li et al (2014) (37) & 1 & 1 & 1 & 1 & 1 & 1 & 1 & 1 & 0 & 1 & 1 & 10 \\
\hline Lira et al (2017) (38) & 0 & 1 & 1 & 1 & 1 & 1 & 1 & 0 & 1 & 0 & 0 & 7 \\
\hline $\begin{array}{l}\text { Martin-Cabezas et al } \\
\text { (2016) (39) }\end{array}$ & 0 & 1 & 1 & 0 & 0 & 1 & 0 & 0 & 1 & 0 & 0 & 4 \\
\hline $\begin{array}{l}\text { Mauri-Obradors et al } \\
(2017)(40)\end{array}$ & 0 & 1 & 1 & 0 & 0 & 1 & 1 & 0 & 0 & 0 & 0 & 4 \\
\hline Orlandi et al (2014) (41) & 0 & 1 & 1 & 1 & 0 & 1 & 1 & 0 & 1 & 1 & 0 & 7 \\
\hline Sanchez et al (2017) (42) & 0 & 0 & 1 & 1 & 0 & 1 & 1 & 0 & 0 & 0 & 0 & 4 \\
\hline Schmitt et al (2015) (43) & 0 & 1 & 1 & 1 & 1 & 1 & 1 & 0 & 1 & 0 & 0 & 7 \\
\hline Teeuw et al (2014) (44) & 0 & 0 & 1 & 0 & 0 & 1 & 1 & 0 & 1 & 1 & 0 & 5 \\
\hline $\begin{array}{l}\text { Tonsekar et al (2017) } \\
\text { (45) }\end{array}$ & 0 & 1 & 1 & 0 & 1 & 1 & 1 & 1 & 0 & 0 & 0 & 6 \\
\hline $\begin{array}{l}\text { Ungprasert et al (2017) } \\
(46)\end{array}$ & 0 & 1 & 1 & 0 & 0 & 1 & 1 & 1 & 1 & 1 & 0 & 7 \\
\hline
\end{tabular}

Abbreviation: AMSTAR, Assessing the Methodological Quality of Systematic Reviews. 
(continued)

Table 1. Results of the Quality Assessment for Included Systematic Reviews Using AMSTAR Checklist, Systematic Umbrella Review of Correlation Between Prevalent Dental Conditions and Chronic Diseases, 1995-2017

\begin{tabular}{|c|c|c|c|c|c|c|c|c|c|c|c|c|}
\hline Study (year) & $\begin{array}{c}\text { 1. A } \\
\text { Priori } \\
\text { Design }\end{array}$ & $\begin{array}{l}\text { 2. Du- } \\
\text { plicate } \\
\text { Selec- } \\
\text { tion }\end{array}$ & $\begin{array}{l}\text { 3. Literat- } \\
\text { ure } \\
\text { Search }\end{array}$ & $\begin{array}{l}\text { 4. Status } \\
\text { of Publica- } \\
\text { tion }\end{array}$ & $\begin{array}{l}\text { 5. List } \\
\text { of } \\
\text { Stud- } \\
\text { ies }\end{array}$ & $\begin{array}{l}\text { 6. Charac- } \\
\text { teristics of } \\
\text { Studies }\end{array}$ & $\begin{array}{l}\text { 7. Qual- } \\
\text { ity of } \\
\text { Studies }\end{array}$ & $\begin{array}{l}\text { 8. Sci- } \\
\text { entific } \\
\text { Quality }\end{array}$ & $\begin{array}{l}\text { 9. Appropri- } \\
\text { ate Meth- } \\
\text { ods }\end{array}$ & $\begin{array}{l}\text { 10. Likeli- } \\
\text { hood of } \\
\text { Bias }\end{array}$ & $\begin{array}{l}\text { 11. Con- } \\
\text { flict of In- } \\
\text { terest }\end{array}$ & Score \\
\hline Xu et al (2017) (47) & 0 & 1 & 1 & 0 & 0 & 1 & 1 & 0 & 1 & 1 & 0 & 6 \\
\hline $\begin{array}{l}\text { Zeng, Leng et al (2016) } \\
\text { (48) }\end{array}$ & 0 & 1 & 1 & 0 & 1 & 1 & 0 & 0 & 1 & 1 & 0 & 6 \\
\hline Zeng et al (2012) (49) & 0 & 1 & 1 & 0 & 0 & 1 & 0 & 0 & 1 & 1 & 0 & 5 \\
\hline $\begin{array}{l}\text { Zeng, Xia et al (2016) } \\
(50)\end{array}$ & 0 & 1 & 1 & 0 & 1 & 1 & 0 & 0 & 1 & 1 & 0 & 6 \\
\hline
\end{tabular}

Abbreviation: AMSTAR, Assessing the Methodological Quality of Systematic Reviews. 
Table 2. Characteristics of Included Systematic Reviews, Systematic Umbrella Review of Correlation Between Prevalent Dental Conditions and Chronic Diseases, 1995-2017

\begin{tabular}{|c|c|c|c|c|c|c|c|c|c|c|}
\hline Study & $\begin{array}{c}\text { Years } \\
\text { Searched }\end{array}$ & $\begin{array}{l}\text { Study } \\
\text { Type(s) }\end{array}$ & Population & $\begin{array}{l}\text { Chronic } \\
\text { Systemic } \\
\text { Disease }\end{array}$ & $\begin{array}{l}\text { Dental } \\
\text { Disease }\end{array}$ & $\begin{array}{l}\text { Interven- } \\
\text { tions }\end{array}$ & Outcome & $\begin{array}{c}\text { Common } \\
\text { Risk } \\
\text { Factors/ } \\
\text { Con- } \\
\text { founders }\end{array}$ & $\begin{array}{l}\text { Quality } \\
\text { Assess- } \\
\text { ment Tool } \\
\text { Used }\end{array}$ & Conclusions \\
\hline $\begin{array}{l}\text { Abdul-jab- } \\
\text { bar, Javed } \\
\text { et al } \\
(2017) \\
(19)\end{array}$ & $\begin{array}{l}\text { Up to } \\
\text { March } \\
2016\end{array}$ & RCTs & $\begin{array}{l}6 \text { Studies, } \\
18-64 \text { pa- } \\
\text { tients per } \\
\text { study }\end{array}$ & T2DM & $\begin{array}{l}\text { Chronic } \\
\text { periodont- } \\
\text { itis }\end{array}$ & $\begin{array}{l}\text { Laser ther- } \\
\text { apy or anti- } \\
\text { microbial } \\
\text { photody- } \\
\text { namic } \\
\text { therapy } \\
\text { after SRP } \\
\end{array}$ & $\begin{array}{l}\text { Clinical period- } \\
\text { ontal out- } \\
\text { comes and gly- } \\
\text { cemic out- } \\
\text { comes }\end{array}$ & NA & Jadad & $\begin{array}{l}\text { LT alone or aPDT showed } \\
\text { significant improvement in } \\
\text { the clinical periodontal para- } \\
\text { meters and glycemic levels } \\
\text { in T2DM patients. Future } \\
\text { RCTs are warranted to con- } \\
\text { firm these findings. }\end{array}$ \\
\hline $\begin{array}{l}\text { Abdul-jab- } \\
\text { bar, Vohra } \\
\text { et al } \\
(2017) \\
(20)\end{array}$ & $\begin{array}{l}\text { Up to Octo- } \\
\text { ber } 2016\end{array}$ & RCTs & $\begin{array}{l}4 \text { Studies, } \\
53-75 \text { pa- } \\
\text { tients per } \\
\text { study }\end{array}$ & DM & $\begin{array}{l}\text { Chronic } \\
\text { periodont- } \\
\text { itis }\end{array}$ & $\begin{array}{l}\text { aPDT plus } \\
\text { SRP/con- } \\
\text { trol SRP } \\
\text { only }\end{array}$ & $\begin{array}{l}\text { Clinical period- } \\
\text { ontal out- } \\
\text { comes and gly- } \\
\text { cemic out- } \\
\text { comes }\end{array}$ & NA & Jadad & $\begin{array}{l}\text { aPDT improved clinical peri- } \\
\text { odontal and glycemic para- } \\
\text { meters in DM patients. } \\
\text { When compared with SRP } \\
\text { alone, none of the studies } \\
\text { showed additional benefits } \\
\text { of aPDT. }\end{array}$ \\
\hline $\begin{array}{l}\text { Al- } \\
\text { Hamoudi } \\
(2017) \\
(21)\end{array}$ & $\begin{array}{l}\text { Up to May } \\
2017\end{array}$ & RCTs & \begin{tabular}{|l|}
6 Studies in \\
Brazil and \\
Saudi Arabia. \\
Number of par- \\
ticipants, \\
$20-30 ; 4$ stud- \\
ies of patients \\
with T2DM, 3 \\
studies with ci- \\
garette \\
smokers
\end{tabular} & T2DM & $\begin{array}{l}\text { Chronic } \\
\text { periodont- } \\
\text { itis }\end{array}$ & $\begin{array}{l}\text { SRP plus } \\
\text { aPDT, } \\
\text { (control } \\
\text { SRP only) }\end{array}$ & $\begin{array}{l}\text { Clinical (PD re- } \\
\text { duction and } \\
\text { CAL gain): mi- } \\
\text { crobiological } \\
\text { (bacterial } \\
\text { count) and im- } \\
\text { munological } \\
\text { (cytokine pro- } \\
\text { file) outcomes }\end{array}$ & Smoking & $\begin{array}{l}\text { Modified } \\
\text { Jadad } \\
\text { quality } \\
\text { scale for } \\
\text { reporting } \\
\text { random- } \\
\text { ized con- } \\
\text { trolled tri- } \\
\text { als }\end{array}$ & $\begin{array}{l}\text { SRP plus aPDT improved } \\
\text { clinical periodontal and im- } \\
\text { munological parameters in } \\
\text { T2DM and cigarette } \\
\text { smokers, no benefits of aP- } \\
\text { DT compared with SRP } \\
\text { alone. }\end{array}$ \\
\hline $\begin{array}{l}\text { Az- } \\
\text { arpazhoo } \\
\text { h and } \\
\text { Leake } \\
(2006) \\
(22)\end{array}$ & $\begin{array}{l}\text { Up to July } \\
2005\end{array}$ & $\begin{array}{l}\text { Case-control } \\
\text { and cross- } \\
\text { sectional for } \\
\text { COPD }\end{array}$ & $\begin{array}{l}\text { Periodontal } \\
\text { disease and } \\
\text { COPD: } 2 \text { cross- } \\
\text { sectional stud- } \\
\text { ies and } 2 \text { case- } \\
\text { control studies; } \\
46 \text { to } 13,792 \\
\text { participants }\end{array}$ & COPD & $\begin{array}{l}\text { Periodont- } \\
\text { al disease, } \\
\text { tooth loss } \\
\text { (dentulous } \\
\text { and eden- } \\
\text { tulous pa- } \\
\text { tients): } \\
\text { dental } \\
\text { plaque }\end{array}$ & $\begin{array}{l}\text { Tooth } \\
\text { brushing, } \\
\text { decontam- } \\
\text { ination/ } \\
\text { rinsing }\end{array}$ & $\begin{array}{l}\text { Risk of pneu- } \\
\text { monia/risk of } \\
\text { COPD }\end{array}$ & NA & NA & $\begin{array}{l}\text { Fair evidence of an associ- } \\
\text { ation of pneumonia with or- } \\
\text { al health, poor evidence } \\
\text { supporting a weak associ- } \\
\text { ation (OR <2.0) between } \\
\text { COPD and oral health, good } \\
\text { evidence (I, grade A recom- } \\
\text { mendation) that oropharyn- } \\
\text { geal decontamination with } \\
\text { different antimicrobial inter- } \\
\text { ventions reduces the pro- } \\
\text { gression or occurrence of } \\
\text { respiratory diseases. }\end{array}$ \\
\hline $\begin{array}{l}\text { Batista et } \\
\text { al (2011) } \\
(23)\end{array}$ & $\begin{array}{l}\text { Up to May } \\
2010\end{array}$ & $\begin{array}{l}\text { Longitudinal, } \\
\text { cross-section- } \\
\text { al, and case- } \\
\text { control stud- } \\
\text { ies, measur- } \\
\text { ing PD and }\end{array}$ & $\begin{array}{l}\text { Longitudinal, } \\
\text { cross-section- } \\
\text { al, and case- } \\
\text { control studies, } \\
\text { measuring PD } \\
\text { and athero- }\end{array}$ & $\begin{array}{l}\text { Athero- } \\
\text { sclerosis }\end{array}$ & $\begin{array}{l}\text { Periodont- } \\
\text { al disease: } \\
\text { measures } \\
\text { not stand- } \\
\text { ardized }\end{array}$ & NA & $\begin{array}{l}\text { Intima-media } \\
\text { thickness (ath- } \\
\text { erosclerosis } \\
\text { measure) }\end{array}$ & $\begin{array}{l}\text { See Table } \\
3 \text { per } \\
\text { study, no } \\
\text { con- } \\
\text { founders } \\
\text { assessed }\end{array}$ & NA & $\begin{array}{l}\text { Although most studies re- } \\
\text { viewed found a positive as- } \\
\text { sociation between PD and } \\
\text { atherosclerosis, methodolo- } \\
\text { gical limitations raise doubts } \\
\text { on the validity. All included }\end{array}$ \\
\hline
\end{tabular}

Abbreviations: AMSTAR, Assessing the Methodological Quality of Systematic Reviews; aPDT, antimicrobial PhotoDynamic Therapy; BMI, body mass index; BMS, burning mouth syndrome; CAL, clinical attachment level (14); CAL, clinical attachment loss (29); CCT, controlled clinical trial; CHD, coronary heart disease; Cl, confidence interval; c-IMT, carotid intima-media thickness; COPD, chronic obstructive pulmonary disease; CRP, C-reactive protein; CsA, cyclosporin A; CVD, cardiovascular disease; DM, diabetes mellitus; FMD, flow-mediated dilation; GRADE Grading of Recommendations, Assessment, Development and Evaluations; HbA1c, glycated hemoglobin; HDL-C, high-density lipoprotein cholesterol; HT, hypertension; ICD, International Classification of Diseases; IL, interleukin; LT, laser therapy; MA, meta-analysis; MI, myocardial infarction; MORE, Methodological Evaluation of Observational Research; NA, not applicable; NOS, Newcastle-Ottowa Scale; OCEBM, Centre for Evidence-Based Medicine, Oxford; OQAQ, Overview Quality Assessment Questionnaire; PD, probing depth; PPD, probing pocket depth; PT, periodontal therapy; PRISMA, Preferred Reporting Items for Systematic Reviews and Meta-Analyses; OR, odds ratio; Ox-LDL, oxidized low-density lipoprotein; RCT, randomized controlled trial; SR, systematic review; SRP, scaling and root planing; T2DM, type 2 diabetes mellitus; TC, total cholesterol; TOAST, Trial of Org 10172 in Acute Stroke Treatment; WBC, white blood cell. 
(continued)

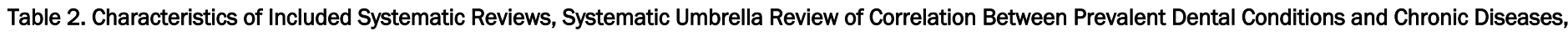
1995-2017

\begin{tabular}{|c|c|c|c|c|c|c|c|c|c|c|}
\hline Study & $\begin{array}{l}\text { Years } \\
\text { Searched }\end{array}$ & $\begin{array}{l}\text { Study } \\
\text { Type(s) }\end{array}$ & Population & $\begin{array}{l}\text { Chronic } \\
\text { Systemic } \\
\text { Disease }\end{array}$ & $\begin{array}{l}\text { Dental } \\
\text { Disease }\end{array}$ & $\begin{array}{l}\text { Interven- } \\
\text { tions }\end{array}$ & Outcome & $\begin{array}{c}\text { Common } \\
\text { Risk } \\
\text { Factors/ } \\
\text { Con- } \\
\text { founders }\end{array}$ & $\begin{array}{l}\text { Quality } \\
\text { Assess- } \\
\text { ment Tool } \\
\text { Used }\end{array}$ & Conclusions \\
\hline & & $\begin{array}{l}\text { atherosclero- } \\
\text { sis clinically }\end{array}$ & $\begin{array}{l}\text { sclerosis clinic- } \\
\text { ally }\end{array}$ & & & & & $\begin{array}{l}\text { in all stud- } \\
\text { ies (mostly } \\
\text { age and } \\
\text { smoking) }\end{array}$ & & $\begin{array}{l}\text { studies found a significant } \\
\text { association. }\end{array}$ \\
\hline $\begin{array}{l}\text { Botero et } \\
\text { al (2016) } \\
(24)\end{array}$ & $\begin{array}{l}1995 \text { to } \\
\text { July } 2015\end{array}$ & $\begin{array}{l}\text { Systematic } \\
\text { reviews, with } \\
\text { or without } \\
\text { meta-analys- } \\
\text { is }\end{array}$ & $\begin{array}{l}13 \text { Systematic } \\
\text { reviews, ran- } \\
\text { ging from } 2 \\
\text { studies with } \\
143 \text { parti- } \\
\text { cipants to } 35 \\
\text { studies with } \\
2,565 \text { parti- } \\
\text { cipants (mostly } \\
\text { included RCTs, } \\
\text { some also non- } \\
\text { RCTs) }\end{array}$ & $\begin{array}{l}\text { DM type } 1 \\
\text { and T2DM }\end{array}$ & $\begin{array}{l}\text { Periodont- } \\
\text { itis }\end{array}$ & $\begin{array}{l}\text { Nonsurgic- } \\
\text { al period- } \\
\text { ontal treat- } \\
\text { ment, } \\
\text { with/ } \\
\text { without an- } \\
\text { tibiotics (2 } \\
\text { studies, } \\
\text { flap sur- } \\
\text { gery) }\end{array}$ & $\begin{array}{l}\text { Glycemic con- } \\
\text { trol: HbA1c or } \\
\text { fasting gluc- } \\
\text { ose levels }\end{array}$ & NA & AMSTAR & $\begin{array}{l}\text { Periodontal treatment could } \\
\text { help improve glycemic con- } \\
\text { trol in patients with T2DM } \\
\text { and periodontitis (10/12 } \\
\text { systematic reviews with } \\
\text { meta-analysis). Whether re- } \\
\text { duction in HbA1c values } \\
\text { (0.23 to } 1.03 \text { percentage } \\
\text { points) is significant for } \\
\text { T2DM treatment and con- } \\
\text { trol is unclear. Impact of PT } \\
\text { in patients with type } 1 \text { dia- } \\
\text { betes and adjunctive antimi- } \\
\text { crobials is inconclusive. } \\
\text { Eight Reviews were of high } \\
\text { quality, } 5 \text { moderate, } 1 \text { low. } \\
\text { Three reviews had low risk } \\
\text { of bias, } 6 \text { were unclear, and } \\
5 \text { high. }\end{array}$ \\
\hline $\begin{array}{l}\text { Dai et al } \\
(2015) \\
(25)\end{array}$ & $\begin{array}{l}\text { Up to } \\
\text { November } \\
2013\end{array}$ & $\begin{array}{l}\text { Observation- } \\
\text { al studies } \\
\text { (clinical trials } \\
\text { were ex- } \\
\text { cluded) }\end{array}$ & $\begin{array}{l}23 \text { Observa- } \\
\text { tional studies: } \\
6 \text { tooth loss, } 4 \\
\text { caries, } 3 \text { oral } \\
\text { hygiene, } 4 \text { peri- } \\
\text { odontal health, } \\
\text { with } 20-706 \\
\text { patients per } \\
\text { study }\end{array}$ & Stroke & $\begin{array}{l}\text { Tooth loss, } \\
\text { periodont- } \\
\text { itis, caries } \\
\text { experience }\end{array}$ & NA & $\begin{array}{l}\text { Oral health out- } \\
\text { comes and or- } \\
\text { al health-re- } \\
\text { lated behaviors }\end{array}$ & $\begin{array}{l}\text { Oral health } \\
\text { behaviors }\end{array}$ & MORE & $\begin{array}{l}\text { Poorer oral health status } \\
\text { among patients with a } \\
\text { stroke diagnosis compared } \\
\text { with healthy controls, great- } \\
\text { er tooth loss, higher dental } \\
\text { caries experience, and } \\
\text { poorer periodontal status. }\end{array}$ \\
\hline $\begin{array}{l}\text { D'Aiuto et } \\
\text { al (2017) } \\
(26)\end{array}$ & $\begin{array}{l}2005-201 \\
5\end{array}$ & $\begin{array}{l}\text { Systematic } \\
\text { reviews/ } \\
\text { meta-ana- } \\
\text { lyses }\end{array}$ & $\begin{array}{l}30 \text { Systematic } \\
\text { reviews: 5-78 } \\
\text { studies in- } \\
\text { cluded per re- } \\
\text { view. Number } \\
\text { of participants } \\
\text { unclear. Vari- } \\
\text { ous types of } \\
\text { studies in- } \\
\text { cluded in sys- } \\
\text { tematic re- } \\
\text { views. }\end{array}$ & DM & $\begin{array}{l}\text { Periodont- } \\
\text { al disease, } \\
\text { tooth loss, } \\
\text { caries }\end{array}$ & NA & $\begin{array}{l}\text { Bidirectional } \\
\text { relationship, or- } \\
\text { al health-dia- } \\
\text { betes }\end{array}$ & NA & AMSTAR & $\begin{array}{l}\text { Strong evidence of T2DM } \\
\text { being a risk factor for peri- } \\
\text { odontal diseases, weak evid- } \\
\text { ence in relation to type } 1 \\
\text { diabetes. Weak evidence in } \\
\text { relation to dental caries ex- } \\
\text { perience in children. Lim- } \\
\text { ited evidence of periodontit- } \\
\text { is being a risk factor for dia- } \\
\text { betes, but evidence of peri- } \\
\text { odontal treatment leading to } \\
\text { modest short-term improve- } \\
\text { ment in glycemic control } \\
\text { (not sustained beyond } 3\end{array}$ \\
\hline
\end{tabular}

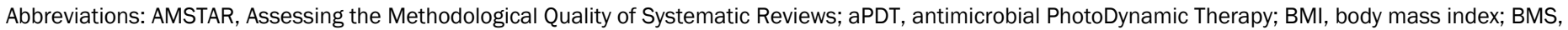

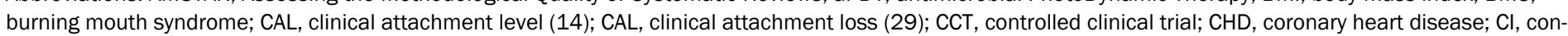

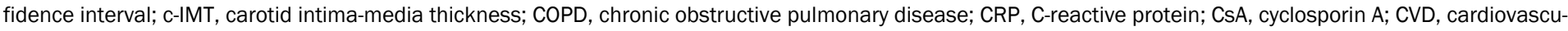

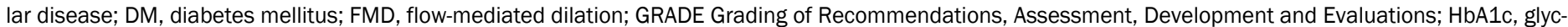

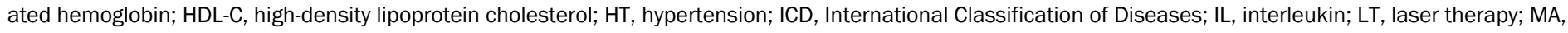

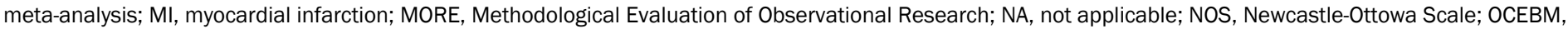

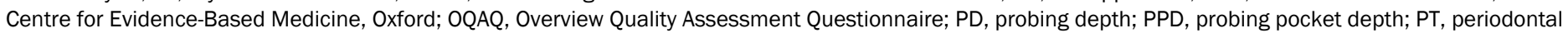

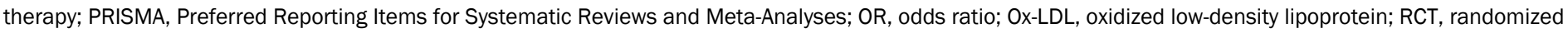

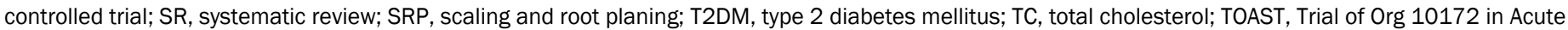
Stroke Treatment; WBC, white blood cell. 
(continued)

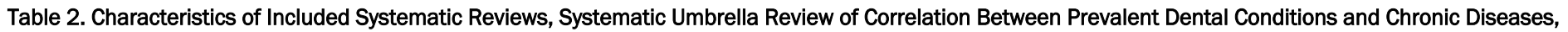
1995-2017

\begin{tabular}{|c|c|c|c|c|c|c|c|c|c|c|}
\hline Study & $\begin{array}{c}\text { Years } \\
\text { Searched }\end{array}$ & $\begin{array}{l}\text { Study } \\
\text { Type(s) }\end{array}$ & Population & $\begin{array}{l}\text { Chronic } \\
\text { Systemic } \\
\text { Disease }\end{array}$ & $\begin{array}{l}\text { Dental } \\
\text { Disease }\end{array}$ & $\begin{array}{l}\text { Interven- } \\
\text { tions }\end{array}$ & Outcome & $\begin{array}{l}\text { Common } \\
\text { Risk } \\
\text { Factors/ } \\
\text { Con- } \\
\text { founders }\end{array}$ & $\begin{array}{l}\text { Quality } \\
\text { Assess- } \\
\text { ment Tool } \\
\text { Used }\end{array}$ & Conclusions \\
\hline & & & & & & & & & & months). \\
\hline $\begin{array}{l}\text { D'Aiuto et } \\
\text { al (2013) } \\
(27)\end{array}$ & $\begin{array}{l}\text { Up to July } \\
2012\end{array}$ & $\begin{array}{l}\text { RCT for meta- } \\
\text { analysis }\end{array}$ & $\begin{array}{l}\text { 14 Studies: } \\
32-160 \text { parti- } \\
\text { cipants per } \\
\text { study }\end{array}$ & CVD & $\begin{array}{l}\text { Periodont- } \\
\text { al disease }\end{array}$ & $\begin{array}{l}\text { SRP or sur- } \\
\text { gical treat- } \\
\text { ment, } \\
\text { tooth ex- } \\
\text { traction, } \\
\text { antibiotics }\end{array}$ & $\begin{array}{l}\text { CVD risk } \\
\text { factors }\end{array}$ & $\begin{array}{l}\text { Biomark- } \\
\text { ers sub- } \\
\text { ject to } \\
\text { methodolo- } \\
\text { gical and } \\
\text { environ- } \\
\text { mental } \\
\text { con- } \\
\text { founders }\end{array}$ & NA & $\begin{array}{l}\text { Main consistent finding after } \\
\text { periodontal therapy was a } \\
\text { reduction of serum levels of } \\
\text { CRP (stable measure of sys- } \\
\text { temic inflammation) and an } \\
\text { improvement of measures } \\
\text { of endothelial function } \\
\text { (which represents a surrog- } \\
\text { ate marker of CVD). }\end{array}$ \\
\hline $\begin{array}{l}\text { Dietrich et } \\
\text { al }(2017) \\
(28)\end{array}$ & $\begin{array}{l}2005-201 \\
5\end{array}$ & $\begin{array}{l}\text { Systematic } \\
\text { reviews and/ } \\
\text { or meta-ana- } \\
\text { lyses }\end{array}$ & $\begin{array}{l}22 \text { Systematic } \\
\text { reviews. 3-89 } \\
\text { studies per } \\
\text { systematic re- } \\
\text { view of various } \\
\text { types. Number } \\
\text { of participants } \\
\text { not reported }\end{array}$ & CVD & $\begin{array}{l}\text { Oral } \\
\text { health: } \\
\text { periodont- } \\
\text { itis, caries, } \\
\text { tooth loss }\end{array}$ & $\begin{array}{l}\text { Oral health } \\
\text { promotion, } \\
\text { periodont- } \\
\text { al treat- } \\
\text { ment }\end{array}$ & NA & NA & $\begin{array}{l}\text { AMSTAR } \\
\text { and } \\
\text { PRISMA }\end{array}$ & $\begin{array}{l}\text { High quality evidence of as- } \\
\text { sociation between CVD and } \\
\text { oral health. Mainly associ- } \\
\text { ation between chronic peri- } \\
\text { odontitis and atherosclerot- } \\
\text { ic heart disease and is inde- } \\
\text { pendent of confounding } \\
\text { factors. No causal relation- } \\
\text { ship has been established. } \\
\text { Firm association between } \\
\text { oral health (periodontitis, } \\
\text { caries and tooth loss) and } \\
\text { atherosclerotic cardiovascu- } \\
\text { lar disease, that is, coronary } \\
\text { heart disease, stroke, and } \\
\text { peripheral vascular disease. } \\
\text { Little or no evidence to sup- } \\
\text { port any links between oral } \\
\text { health and other forms of } \\
\text { cardiovascular disease that } \\
\text { are non-atherosclerotic such } \\
\text { as HT, arrhythmias, and } \\
\text { heart failure. Periodontal } \\
\text { therapy is associated with } \\
\text { reductions in surrogate } \\
\text { markers of atherosclerotic } \\
\text { CVD. }\end{array}$ \\
\hline $\begin{array}{l}\text { Faggion et } \\
\text { al (2016) } \\
(29)\end{array}$ & $\begin{array}{l}\text { Up to } \\
\text { March } \\
2015\end{array}$ & $\begin{array}{l}\text { Systematic } \\
\text { reviews with } \\
\text { meta-analys- } \\
\text { is }\end{array}$ & $\begin{array}{l}11 \text { Meta-ana- } \\
\text { lyses, original } \\
\text { studies based } \\
\text { on } 12-514 \text { pa- } \\
\text { tients }\end{array}$ & $\begin{array}{l}\text { DM type } 1 \\
\text { and T2DM }\end{array}$ & $\begin{array}{l}\text { Periodont- } \\
\text { al disease }\end{array}$ & $\begin{array}{l}\text { Periodont- } \\
\text { al treat- } \\
\text { ment }\end{array}$ & HbA1c levels & NA & $\begin{array}{l}\text { AMSTAR } \\
\text { and OQAQ }\end{array}$ & $\begin{array}{l}\text { SRs showing an average de- } \\
\text { crease of } 0.46 \% \text { (median, } \\
0.40 \% \text { ) of HbA1c levels. } \\
\text { These values, nevertheless, } \\
\text { are not significant when } \\
\text { meta-analyses of longer fol- } \\
\text { low-ups (up to } 6 \text { mos) are } \\
\text { evaluated. Furthermore, } \\
\text { most primary studies in- }\end{array}$ \\
\hline
\end{tabular}

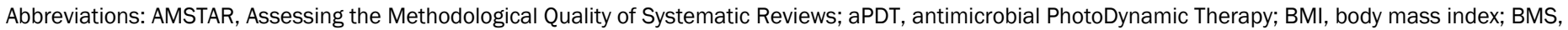

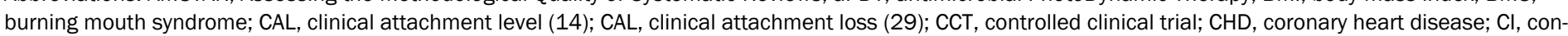

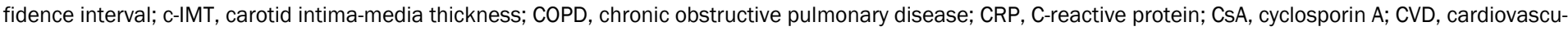

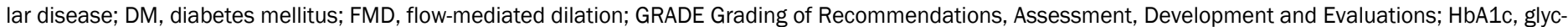

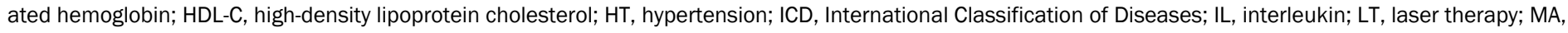

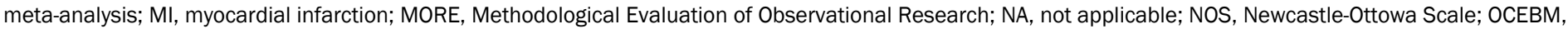

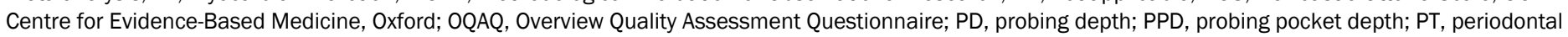

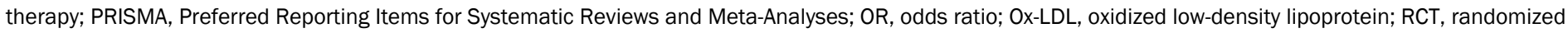

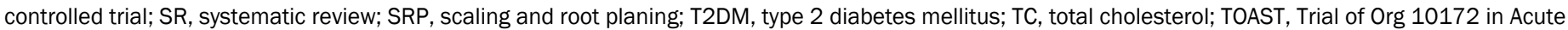
Stroke Treatment; WBC, white blood cell.

(continued on next page)

The opinions expressed by authors contributing to this journal do not necessarily reflect the opinions of the U.S. Department of Health and Human Services, the Public Health Service, the Centers for Disease Control and Prevention, or the authors' affiliated institutions. 
(continued)

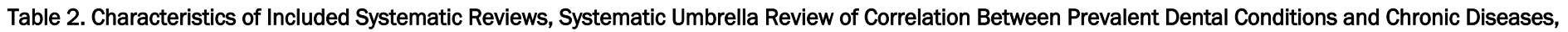
1995-2017

\begin{tabular}{|c|c|c|c|c|c|c|c|c|c|c|}
\hline Study & $\begin{array}{c}\text { Years } \\
\text { Searched }\end{array}$ & $\begin{array}{l}\text { Study } \\
\text { Type(s) }\end{array}$ & Population & $\begin{array}{l}\text { Chronic } \\
\text { Systemic } \\
\text { Disease }\end{array}$ & $\begin{array}{l}\text { Dental } \\
\text { Disease }\end{array}$ & $\begin{array}{l}\text { Interven- } \\
\text { tions }\end{array}$ & Outcome & $\begin{array}{l}\text { Common } \\
\text { Risk } \\
\text { Factors/ } \\
\text { Con- } \\
\text { founders }\end{array}$ & $\begin{array}{l}\text { Quality } \\
\text { Assess- } \\
\text { ment Tool } \\
\text { Used }\end{array}$ & Conclusions \\
\hline & & & & & & & & & & $\begin{array}{l}\text { cluded in those SRs had } \\
\text { several methodological limit- } \\
\text { ations. }\end{array}$ \\
\hline $\begin{array}{l}\text { Hasuike } \\
\text { et al } \\
(2017) \\
(30)\end{array}$ & $\begin{array}{l}\text { Up to July } \\
2015\end{array}$ & $\begin{array}{l}\text { Systematic } \\
\text { reviews with } \\
\text { meta-analys- } \\
\text { is }\end{array}$ & $\begin{array}{l}9 \text { Studies, } \\
60-1,135 \text { par- } \\
\text { ticipants }\end{array}$ & $\begin{array}{l}\text { DM type } 1 \\
\text { and T2DM }\end{array}$ & $\begin{array}{l}\text { Periodont- } \\
\text { al disease }\end{array}$ & $\begin{array}{l}\text { Periodont- } \\
\text { al treat- } \\
\text { ment with } \\
\text { or without } \\
\text { adjunctive } \\
\text { use of loc- } \\
\text { al drug de- } \\
\text { livery and } \\
\text { systemic } \\
\text { antibiotics. }\end{array}$ & $\begin{array}{l}\text { Changes in } \\
\text { HbA1c }\end{array}$ & NA & AMSTAR & $\begin{array}{l}\text { Significant effect of period- } \\
\text { ontal treatment on improve- } \\
\text { ment of HbA1c levels in dia- } \\
\text { betes patients, although ef- } \\
\text { fect size is extremely small. } \\
\text { In addition to this small ef- } \\
\text { fect size, the supporting } \\
\text { evidence cannot be re- } \\
\text { garded as high quality. }\end{array}$ \\
\hline $\begin{array}{l}\text { Kelly et al } \\
(2013) \\
(31)\end{array}$ & $\begin{array}{l}\text { Up to May } \\
2012\end{array}$ & $\begin{array}{l}\text { Systematic } \\
\text { reviews }\end{array}$ & $\begin{array}{l}13 \text { Systematic } \\
\text { reviews, } 9 \text { with } \\
\text { meta-analyses. } \\
\text { Not reported } \\
\text { how many } \\
\text { studies were } \\
\text { included in } \\
\text { each systemat- } \\
\text { ic review }\end{array}$ & $\begin{array}{l}\text { Chronic } \\
\text { heart dis- } \\
\text { ease }\end{array}$ & $\begin{array}{l}\text { Periodont- } \\
\text { al disease }\end{array}$ & NA & $\begin{array}{l}\text { Quality apprais- } \\
\text { al }\end{array}$ & NA & $\begin{array}{l}\text { AMSTAR } \\
\text { and Glenny } \\
\text { et al (51) }\end{array}$ & $\begin{array}{l}\text { Apart from analyzing the } \\
\text { methodological and structur- } \\
\text { al quality of the selected } \\
\text { systematic reviews and } \\
\text { meta-analyses, we did not } \\
\text { attempt to perform any out- } \\
\text { come analyses. There was } \\
\text { substantial heterogeneity in } \\
\text { the types of articles in- } \\
\text { cluded in the } 13 \text { reviews, } \\
\text { with varying study designs } \\
\text { including cohort, cross-sec- } \\
\text { tional, case-control, and } \\
\text { RCTs. }\end{array}$ \\
\hline $\begin{array}{l}\text { Kothari et } \\
\text { al (2017) } \\
(32)\end{array}$ & $\begin{array}{l}\text { Through } \\
\text { January } \\
2016\end{array}$ & $\begin{array}{l}\text { Observation- } \\
\text { al studies, } \\
\text { case-control } \\
\text { studies, and } \\
1 \text { mixed- } \\
\text { methods } \\
\text { study }\end{array}$ & $\begin{array}{l}27 \text { Studies; no } \\
\text { information on } \\
\text { number of par- } \\
\text { ticipants per } \\
\text { study }\end{array}$ & $\begin{array}{l}\text { Acquired } \\
\text { brain in- } \\
\text { jury, in- } \\
\text { cluding } \\
\text { cerebrova } \\
\text { scular dis- } \\
\text { eases }\end{array}$ & $\begin{array}{l}\text { Tooth loss, } \\
\text { periodont- } \\
\text { al status, } \\
\text { caries }\end{array}$ & $\begin{array}{l}\text { Profes- } \\
\text { sional oral } \\
\text { health } \\
\text { care or or- } \\
\text { al hygiene } \\
\text { instruc- } \\
\text { tion (in } \\
\text { some stud- } \\
\text { ies) }\end{array}$ & NA & NA & NA & $\begin{array}{l}\text { Currently low level of in- } \\
\text { terest in topic. All included } \\
\text { studies reported poor oral } \\
\text { health in patients with brain } \\
\text { injury. Studies also showed } \\
\text { significant improvements in } \\
\text { oral health if appropriate } \\
\text { measures were implemen- } \\
\text { ted at rehabilitation settings. } \\
\text { Stroke patients seemed to } \\
\text { present with higher incid- } \\
\text { ence of missing teeth and } \\
\text { tooth mobility. }\end{array}$ \\
\hline $\begin{array}{l}\text { Lafon et } \\
\text { al (2014) } \\
(33)\end{array}$ & $\begin{array}{l}\text { Up to April } \\
2012\end{array}$ & $\begin{array}{l}\text { Cohort stud- } \\
\text { ies }\end{array}$ & $\begin{array}{l}9 \text { Studies: } 5 \text { in } \\
\text { North America, } \\
\text { started during } \\
\text { 1970-1980. } \\
\text { Participants } \\
\text { ranged from }\end{array}$ & Stroke & $\begin{array}{l}\text { Periodont- } \\
\text { al disease }\end{array}$ & NA & $\begin{array}{l}\text { Periodontitis } \\
\text { and tooth loss }\end{array}$ & NA & $\begin{array}{l}\text { Evaluation } \\
\text { grid }\end{array}$ & $\begin{array}{l}\text { Results suggested a link } \\
\text { between stroke and period- } \\
\text { ontal diseases. The associ- } \\
\text { ation was significant for peri- } \\
\text { odontitis and tooth loss. The } \\
\text { risk of ischemic or hemor- }\end{array}$ \\
\hline
\end{tabular}

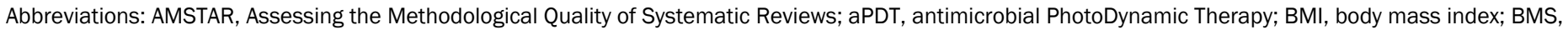

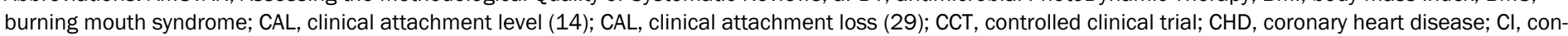

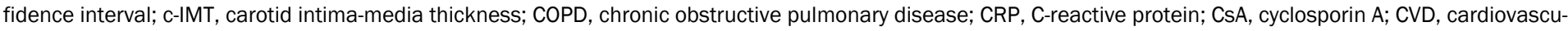

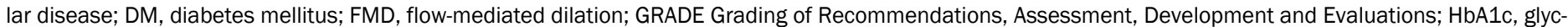

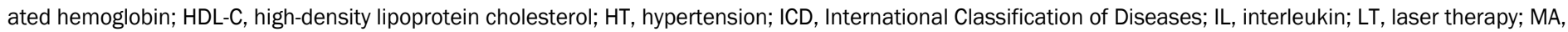

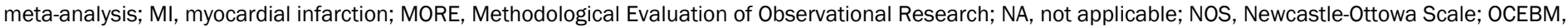

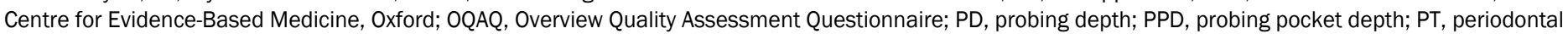

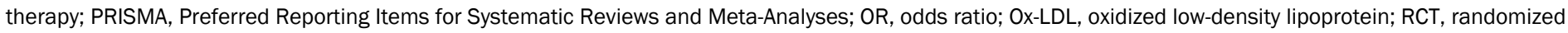

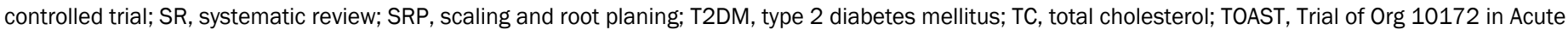
Stroke Treatment; WBC, white blood cell. 
(continued)

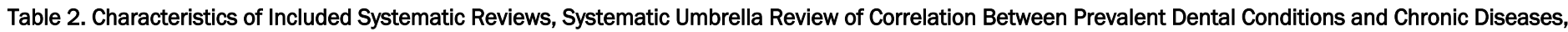
1995-2017

\begin{tabular}{|c|c|c|c|c|c|c|c|c|c|c|}
\hline Study & $\begin{array}{c}\text { Years } \\
\text { Searched }\end{array}$ & $\begin{array}{l}\text { Study } \\
\text { Type(s) }\end{array}$ & Population & $\begin{array}{l}\text { Chronic } \\
\text { Systemic } \\
\text { Disease }\end{array}$ & $\begin{array}{l}\text { Dental } \\
\text { Disease }\end{array}$ & $\begin{array}{l}\text { Interven- } \\
\text { tions }\end{array}$ & Outcome & $\begin{array}{l}\text { Common } \\
\text { Risk } \\
\text { Factors/ } \\
\text { Con- } \\
\text { founders }\end{array}$ & $\begin{array}{l}\text { Quality } \\
\text { Assess- } \\
\text { ment Tool } \\
\text { Used }\end{array}$ & Conclusions \\
\hline & & & $\begin{array}{l}1,137-51,529 \\
\text {. Length of fol- } \\
\text { low-up from } \\
12-57 \text { years }\end{array}$ & & & & & & & $\begin{array}{l}\text { rhagic stroke was higher in } \\
\text { people with periodontitis } \\
\text { (estimated adjusted risk, } \\
1.63[1.25-2.00]) \text {. Tooth } \\
\text { loss was also a significant } \\
\text { risk factor for stroke (estim- } \\
\text { ated adjusted risk, } 1.39 \\
{[1.13-1.65] \text { ). In this review, }} \\
\text { gingivitis did not signific- } \\
\text { antly influence the occur- } \\
\text { rence of stroke. }\end{array}$ \\
\hline $\begin{array}{l}\text { Lam et al } \\
(2011) \\
(34)\end{array}$ & NA & $\begin{array}{l}3 \text { RCTs, } 3 \\
\text { pre-post in- } \\
\text { terventions, } \\
1 \text { split- } \\
\text { mouth, } 1 \\
\text { quasi-experi- } \\
\text { mental }\end{array}$ & $\begin{array}{l}8 \text { Studies, ran- } \\
\text { ging from } \\
6-303 \text { pa- } \\
\text { tients }\end{array}$ & CVD & $\begin{array}{l}\text { Oral } \\
\text { health: } \\
\text { periodont- } \\
\text { al health }\end{array}$ & $\begin{array}{l}\text { Oral health } \\
\text { instruc- } \\
\text { tion, ex- } \\
\text { tractions, } \\
\text { periodont- } \\
\text { al treat- } \\
\text { ment }\end{array}$ & $\begin{array}{l}\text { Periodontal } \\
\text { health and } \\
\text { changes in sys- } \\
\text { temic blood } \\
\text { marker levels }\end{array}$ & NA & NA & $\begin{array}{l}\text { Periodontal interventions } \\
\text { were found to be capable of } \\
\text { modifying numerous surrog- } \\
\text { ate markers of cardiovascu- } \\
\text { lar outcomes including CRP, } \\
\text { Ox-LDL, WBC, fibrinogen, IL- } \\
6 \text {, and endothelial dysfunc- } \\
\text { tion. It must be accepted, } \\
\text { however, that neither a } \\
\text { cause-and-effect relation- } \\
\text { ship, nor the exact mechan- } \\
\text { ism whereby periodontal dis- } \\
\text { ease may affect cardiovas- } \\
\text { cular disease risk has been } \\
\text { established. Whether the re- } \\
\text { duction of systemic inflam- } \\
\text { matory markers can truly de- } \\
\text { crease the risk of secondary } \\
\text { cardiovascular events re- } \\
\text { mains to be shown by stud- } \\
\text { ies of longer duration. Inter- } \\
\text { ventions aimed at improv- } \\
\text { ing periodontal parameters } \\
\text { such as plaque and gingival } \\
\text { bleeding were successful in } \\
\text { patients with HT, CHD, and } \\
\text { previous heart transplanta- } \\
\text { tion. Periodontal interven- } \\
\text { tions were less successful at } \\
\text { effecting changes in CsA-in- } \\
\text { duced gingival overgrowth in } \\
\text { heart transplantation pa- } \\
\text { tients. None of the effective } \\
\text { articles included assess- } \\
\text { ments on the effect of oral } \\
\text { promotion interventions on } \\
\text { oral microflora. }\end{array}$ \\
\hline
\end{tabular}

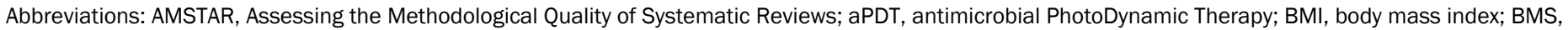

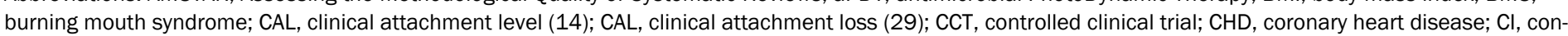

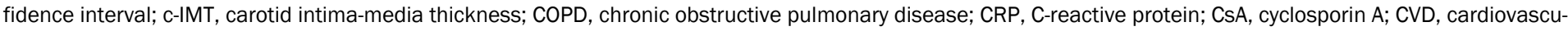

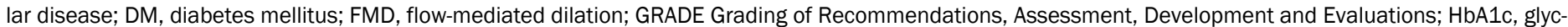

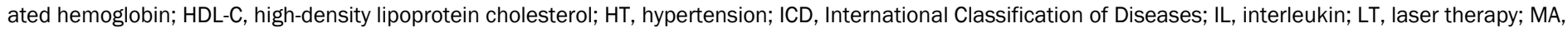

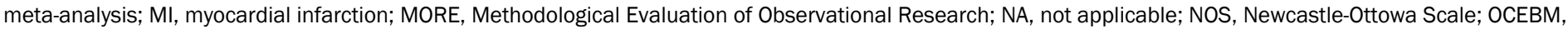

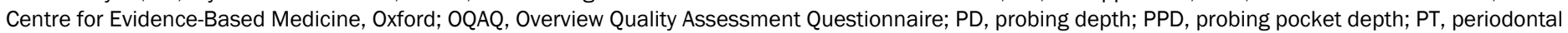

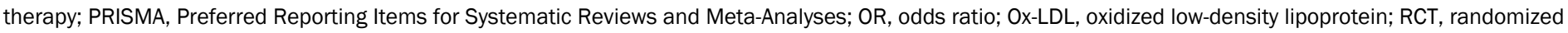

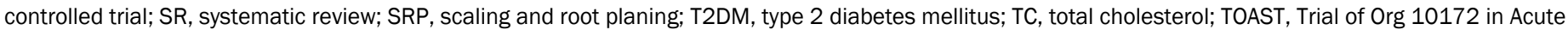
Stroke Treatment; WBC, white blood cell.

(continued on next page)

The opinions expressed by authors contributing to this journal do not necessarily reflect the opinions of the U.S. Department of Health and Human Services, the Public Health Service, the Centers for Disease Control and Prevention, or the authors' affiliated institutions. 
(continued)

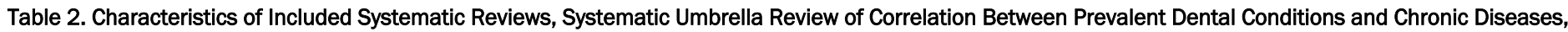
1995-2017

\begin{tabular}{|c|c|c|c|c|c|c|c|c|c|c|}
\hline Study & $\begin{array}{c}\text { Years } \\
\text { Searched }\end{array}$ & $\begin{array}{l}\text { Study } \\
\text { Type(s) }\end{array}$ & Population & $\begin{array}{l}\text { Chronic } \\
\text { Systemic } \\
\text { Disease }\end{array}$ & $\begin{array}{l}\text { Dental } \\
\text { Disease }\end{array}$ & $\begin{array}{l}\text { Interven- } \\
\text { tions }\end{array}$ & Outcome & $\begin{array}{l}\text { Common } \\
\text { Risk } \\
\text { Factors/ } \\
\text { Con- } \\
\text { founders }\end{array}$ & $\begin{array}{l}\text { Quality } \\
\text { Assess- } \\
\text { ment Tool } \\
\text { Used }\end{array}$ & Conclusions \\
\hline $\begin{array}{l}\text { Leira et al } \\
(2017) \\
(35)\end{array}$ & $\begin{array}{l}\text { Up to } \\
\text { March } \\
2015\end{array}$ & $\begin{array}{l}3 \text { cohort (ret- } \\
\text { rospective } \\
\text { and prospect- } \\
\text { ive), } 5 \text { case- } \\
\text { control stud- } \\
\text { ies }\end{array}$ & $\begin{array}{l}8 \text { Studies, } \\
95-9,962 \text { pa- } \\
\text { tients. Europe, } \\
\text { North America, } \\
\text { and Asia. Data } \\
\text { collected } \\
\text { between } 1968 \\
\text { and } 2012\end{array}$ & $\begin{array}{l}\text { Ischemic } \\
\text { stroke (as- } \\
\text { sessed as } \\
\text { acute } \\
\text { ischemic } \\
\text { lesion on } \\
\text { brain ima- } \\
\text { ging and/ } \\
\text { or neurolo- } \\
\text { gical defi- } \\
\text { cit, TOAST } \\
\text { and ICD) }\end{array}$ & $\begin{array}{l}\text { Periodont- } \\
\text { itis (as- } \\
\text { sessed } \\
\text { with CAL, } \\
\text { PPD, and } \\
\text { radio- } \\
\text { graphic } \\
\text { bone loss) }\end{array}$ & NA & $\begin{array}{l}\text { Risk of ischem- } \\
\text { ic stroke }\end{array}$ & $\begin{array}{l}\text { Most com- } \\
\text { monly ad- } \\
\text { justed vas- } \\
\text { cular risk } \\
\text { factors } \\
\text { were: age, } \\
\text { sex, DM, } \\
\text { HT, } \\
\text { smoking } \\
\text { status, hy- } \\
\text { percholes- } \\
\text { terolemia, } \\
\text { and BMI }\end{array}$ & GRADE & $\begin{array}{l}\text { Suggested a positive associ- } \\
\text { ation between ischemic } \\
\text { stroke and prevalence of } \\
\text { periodontitis. The risk of } \\
\text { cerebral ischemia was high- } \\
\text { er in subjects with period- } \\
\text { ontitis (RR, } 2.88 \text { [95\% Cl, } \\
1.53-5.41]) \text {. }\end{array}$ \\
\hline $\begin{array}{l}\text { Leng et al } \\
(2015) \\
(36)\end{array}$ & $\begin{array}{l}\text { Up to May } \\
2015\end{array}$ & $\begin{array}{l}\text { Prospective } \\
\text { cohort stud- } \\
\text { ies }\end{array}$ & $\begin{array}{l}15 \text { Studies en- } \\
\text { rolling } \\
230-406 \text { par- } \\
\text { ticipants }\end{array}$ & $\begin{array}{l}\text { Coronary } \\
\text { heart dis- } \\
\text { ease }\end{array}$ & $\begin{array}{l}\text { Periodont- } \\
\text { al disease }\end{array}$ & NA & $\begin{array}{l}\text { CHD-related } \\
\text { morbidity (fatal } \\
\text { and nonfatal) } \\
\text { or mortality, } \\
\text { evaluated us- } \\
\text { ing relative risk } \\
\text { or hazard ratio }\end{array}$ & $\begin{array}{l}\text { Sex, BMI, } \\
\text { smoking, } \\
\text { age, fam- } \\
\text { ily history } \\
\text { of heart } \\
\text { disease, } \\
\text { education, } \\
\text { blood pres- } \\
\text { sure (most } \\
\text { common } \\
\text { con- } \\
\text { founders) }\end{array}$ & NA & $\begin{array}{l}\text { Patients with periodontal } \\
\text { disease were at a signific- } \\
\text { antly increased risk of devel- } \\
\text { oping CHD (RR, } 1.19 ; 95 \% \\
\mathrm{Cl}, 1.13-1.26 ; P<.001) \text {. } \\
\text { Subgroup analyses accord- } \\
\text { ing to the effect measure, } \\
\text { adjustment for confounding } \\
\text { factors, median follow-up } \\
\text { time, country of study origin, } \\
\text { assessment method of peri- } \\
\text { odontal disease, and sex all } \\
\text { indicated significant associ- } \\
\text { ations between periodontal } \\
\text { disease and CHD. }\end{array}$ \\
\hline $\begin{array}{l}\text { Li et al } \\
(2014) \\
(37)\end{array}$ & $\begin{array}{l}\text { Up to April } \\
2014\end{array}$ & $\begin{array}{l}\text { RCT and } \\
\text { quasi-RCT }\end{array}$ & $\begin{array}{l}1 \mathrm{RCT}, 303 \\
\text { participants }\end{array}$ & CVD & $\begin{array}{l}\text { Chronic } \\
\text { periodont- } \\
\text { itis }\end{array}$ & $\begin{array}{l}\text { SRP and } \\
\text { com- } \\
\text { munity } \\
\text { care }\end{array}$ & $\begin{array}{l}\text { Cardiovascular } \\
\text { events }\end{array}$ & NA & $\begin{array}{l}\text { Cochrane's } \\
\text { RoB as- } \\
\text { sessment } \\
\text { tool, } \\
\text { GRADE }\end{array}$ & $\begin{array}{l}\text { The study recorded } 12 \text { cardi- } \\
\text { ovascular events, but res- } \\
\text { ults were not significant. } \\
\text { Also, serum high sensitivity } \\
\text { CRP: who had high CRP, and } \\
\text { adverse events all reported } \\
\text { nonsignificant results. Be- } \\
\text { cause only } 1 \text { was study eli- } \\
\text { gible for inclusion, which } \\
\text { was also judged to be at } \\
\text { high risk of bias, the results } \\
\text { should be interpreted with } \\
\text { caution. }\end{array}$ \\
\hline $\begin{array}{l}\text { Lira et al } \\
(2017) \\
(38)\end{array}$ & $\begin{array}{l}\text { Up to } \\
\text { Septem- } \\
\text { ber } 2016\end{array}$ & Clinical trials & $\begin{array}{l}12 \text { Studies } \\
\text { qualitative ana- } \\
\text { lysis; } 8 \text { meta- } \\
\text { analyses, } \\
30-70 \text { pa- }\end{array}$ & DM & $\begin{array}{l}\text { Periodont- } \\
\text { al disease }\end{array}$ & $\begin{array}{l}\text { Adjunctive } \\
\text { use of sys- } \\
\text { temic anti- } \\
\text { biotics in } \\
\text { nonsurgic- }\end{array}$ & $\begin{array}{l}\text { Changes in } \\
\text { HbA1c }\end{array}$ & NA & $\begin{array}{l}\text { Cochrane's } \\
\text { RoB as- } \\
\text { sessment } \\
\text { tool }\end{array}$ & $\begin{array}{l}\text { Shows no additional benefit } \\
\text { of associating systemic anti- } \\
\text { biotics to nonsurgical peri- } \\
\text { odontal treatment versus } \\
\text { SRP alone in improving }\end{array}$ \\
\hline
\end{tabular}

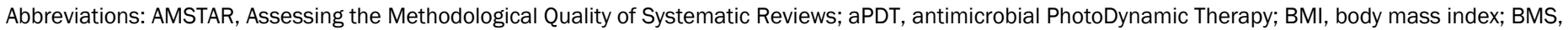

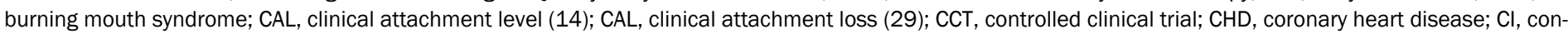

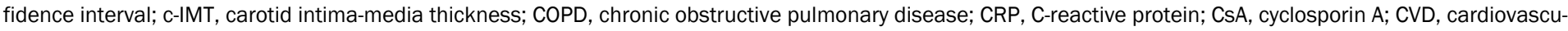

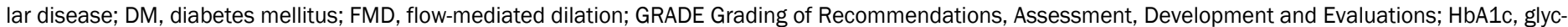

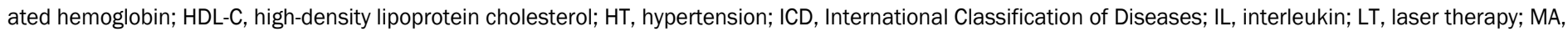

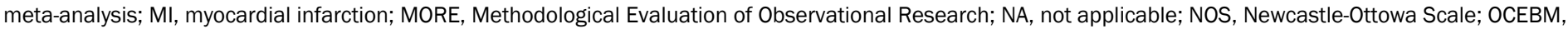

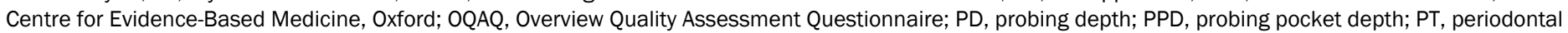

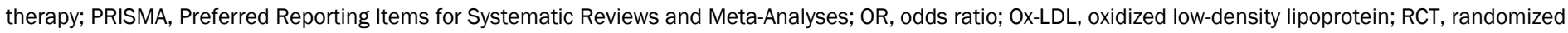

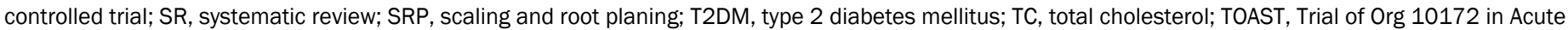
Stroke Treatment; WBC, white blood cell. 
(continued)

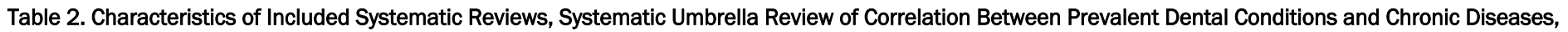
1995-2017

\begin{tabular}{|c|c|c|c|c|c|c|c|c|c|c|}
\hline Study & $\begin{array}{l}\text { Years } \\
\text { Searched }\end{array}$ & $\begin{array}{l}\text { Study } \\
\text { Type(s) }\end{array}$ & Population & $\begin{array}{l}\text { Chronic } \\
\text { Systemic } \\
\text { Disease }\end{array}$ & $\begin{array}{l}\text { Dental } \\
\text { Disease }\end{array}$ & $\begin{array}{l}\text { Interven- } \\
\text { tions }\end{array}$ & Outcome & $\begin{array}{l}\text { Common } \\
\text { Risk } \\
\text { Factors/ } \\
\text { Con- } \\
\text { founders }\end{array}$ & $\begin{array}{l}\text { Quality } \\
\text { Assess- } \\
\text { ment Tool } \\
\text { Used }\end{array}$ & Conclusions \\
\hline & & & $\begin{array}{l}\text { tients per } \\
\text { study }\end{array}$ & & & $\begin{array}{l}\text { al period- } \\
\text { ontal treat- } \\
\text { ment, } \\
\text { compared } \\
\text { with non- } \\
\text { surgical } \\
\text { periodont- } \\
\text { al treat- } \\
\text { ment } \\
\text { alone. }\end{array}$ & & & & $\begin{array}{l}\text { HbA1c levels } 3-4 \text { months } \\
\text { after treatment. }\end{array}$ \\
\hline $\begin{array}{l}\text { Martin- } \\
\text { Cabezas } \\
\text { et al } \\
(2016) \\
(39)\end{array}$ & $\begin{array}{l}2000 \text { to } \\
\text { June } 2016\end{array}$ & $\begin{array}{l}\text { Longitudinal } \\
\text { studies or } \\
\text { case-control } \\
\text { studies and } \\
\text { cross-section- } \\
\text { al studies }\end{array}$ & $\begin{array}{l}25 \text { Studies in } \\
\text { review; } 18 \text { in } \\
\text { meta-analysis: } \\
20 \text { cross-sec- } \\
\text { tional, } 3 \text { case- } \\
\text { control, and } 2 \\
\text { Iongitudinal } \\
\text { studies, across } \\
\text { Asia, Europe, } \\
\text { United States, } \\
\text { and Africa. } \\
\text { Ranging from } \\
8,124-1,025, \\
340 \text { parti- } \\
\text { cipants. }\end{array}$ & HT & $\begin{array}{l}\text { Periodont- } \\
\text { al disease }\end{array}$ & NA & HT & $\begin{array}{l}\text { Age, sex, } \\
\text { smoking, } \\
\text { BMI, binge } \\
\text { drinking }\end{array}$ & NOS & $\begin{array}{l}\text { Results from the present } \\
\text { meta-analysis support the } \\
\text { association between HT and } \\
\text { periodontal diseases with a } \\
\text { range of ORs from } 1.15 \text { to } \\
1.67 \text {. Highest OR was calcu- } \\
\text { lated when severe form of } \\
\text { periodontitis with secure } \\
\text { diagnosis criteria was con- } \\
\text { sidered (OR, 1.64). }\end{array}$ \\
\hline $\begin{array}{l}\text { Mauri- } \\
\text { Obradors } \\
\text { et al } \\
(2017) \\
(40)\end{array}$ & $\begin{array}{l}1998 \text { to } \\
\text { January } \\
2016\end{array}$ & $\begin{array}{l}\text { Primary stud- } \\
\text { ies }\end{array}$ & $\begin{array}{l}19 \text { Studies: } 4 \times \\
\text { longitudinal } \\
\text { studies; } 15 \times \\
\text { cross-section- } \\
\text { al studies. A } \\
\text { total of } 3,712 \\
\text { patients, of } \\
\text { whom } 2,084 \\
\text { had diabetes. }\end{array}$ & $\begin{array}{l}\text { DM type } 1 \\
\text { and T2DM }\end{array}$ & $\begin{array}{l}\text { Caries, } \\
\text { periodont- } \\
\text { al disease, } \\
\text { BMS, oral } \\
\text { mucosa al- } \\
\text { terations }\end{array}$ & NA & $\begin{array}{l}\text { Oral manifesta- } \\
\text { tions }\end{array}$ & NA & $\begin{array}{l}\text { Recom- } \\
\text { menda- } \\
\text { tions made } \\
\text { by OCEBM }\end{array}$ & $\begin{array}{l}\text { DM leads to multiple com- } \\
\text { plications, which increase } \\
\text { when glycemic control of the } \\
\text { patient is inadequate. The } \\
\text { main oral complication at- } \\
\text { tributed to diabetes is peri- } \\
\text { odontal disease: considered } \\
\text { the sixth complication of } \\
\text { DM. Higher prevalence of } \\
\text { periapical lesions in pa- } \\
\text { tients with poorly controlled } \\
\text { diabetes. Information } \\
\text { presented in the literature } \\
\text { about the relationship } \\
\text { between the DM and tooth } \\
\text { decay is inconsistent. }\end{array}$ \\
\hline $\begin{array}{l}\text { Orlandi et } \\
\text { al (2014) } \\
(41)\end{array}$ & $\begin{array}{l}\text { Through } \\
\text { January } \\
2014\end{array}$ & $\begin{array}{l}\text { Cross-sec- } \\
\text { tional stud- } \\
\text { ies, case-con- } \\
\text { trol studies, } \\
\text { population }\end{array}$ & $\begin{array}{l}35 \text { Studies for } \\
\text { systematic re- } \\
\text { view, } 22 \text { stud- } \\
\text { ies for meta- } \\
\text { analysis; } 2,021\end{array}$ & $\begin{array}{l}\text { C-IMT; } \\
\text { FMD }\end{array}$ & $\begin{array}{l}\text { Periodont- } \\
\text { itis }\end{array}$ & $\begin{array}{l}\text { Periodont- } \\
\text { al inter- } \\
\text { vention }\end{array}$ & $\begin{array}{l}\text { Increase in c- } \\
\text { IMT. Effects of } \\
\text { periodontal } \\
\text { treatment on } \\
\text { FMD. }\end{array}$ & $\begin{array}{l}\text { CVD (age, } \\
\text { sex, systol- } \\
\text { ic blood } \\
\text { pressure, } \\
\text { HDL-C, }\end{array}$ & $\begin{array}{l}\text { Newcastle- } \\
\text { Ottawa } \\
\text { Quality As- } \\
\text { sessment } \\
\text { Scale }\end{array}$ & $\begin{array}{l}\text { Diagnosis of PD was associ- } \\
\text { ated with a mean increase } \\
\text { in c-IMT of } 0.08 \mathrm{~mm}(95 \% \\
\mathrm{Cl}, 0.07-0.09 \mathrm{~mm}) \text { and a } \\
\text { mean difference in FMD of }\end{array}$ \\
\hline
\end{tabular}

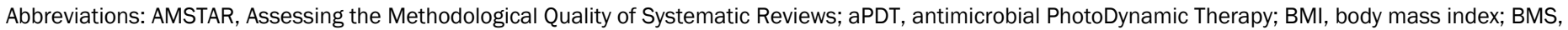

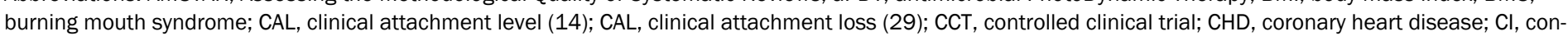

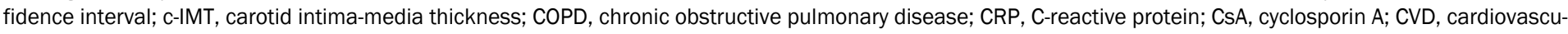

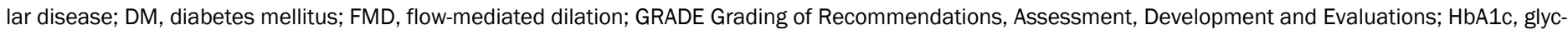

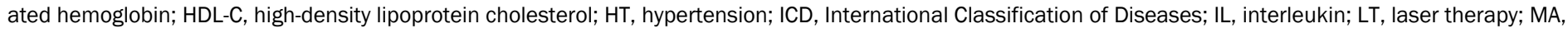

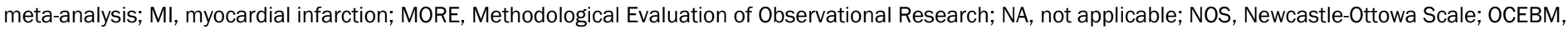

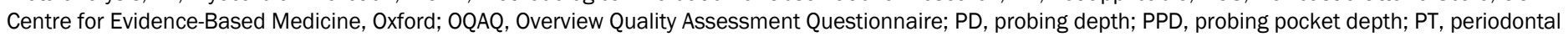

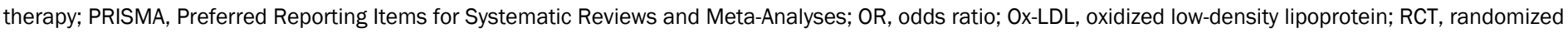

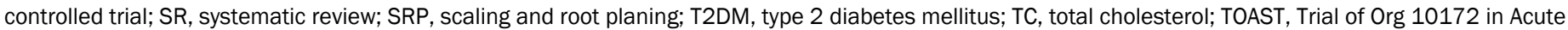
Stroke Treatment; WBC, white blood cell.

(continued on next page)

The opinions expressed by authors contributing to this journal do not necessarily reflect the opinions of the U.S. Department of Health and Human Services, the Public Health Service, the Centers for Disease Control and Prevention, or the authors' affiliated institutions. 
(continued)

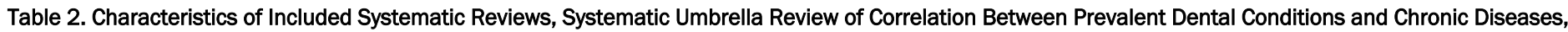
1995-2017

\begin{tabular}{|c|c|c|c|c|c|c|c|c|c|c|}
\hline Study & $\begin{array}{c}\text { Years } \\
\text { Searched }\end{array}$ & $\begin{array}{l}\text { Study } \\
\text { Type(s) }\end{array}$ & Population & $\begin{array}{l}\text { Chronic } \\
\text { Systemic } \\
\text { Disease }\end{array}$ & $\begin{array}{l}\text { Dental } \\
\text { Disease }\end{array}$ & $\begin{array}{l}\text { Interven- } \\
\text { tions }\end{array}$ & Outcome & $\begin{array}{c}\text { Common } \\
\text { Risk } \\
\text { Factors/ } \\
\text { Con- } \\
\text { founders }\end{array}$ & $\begin{array}{c}\text { Quality } \\
\text { Assess- } \\
\text { ment Tool } \\
\text { Used }\end{array}$ & Conclusions \\
\hline & & $\begin{array}{l}\text { surveys, co- } \\
\text { hort studies, } \\
\text { pilot studies, } \\
\text { controlled tri- } \\
\text { als, RCTs }\end{array}$ & $\begin{array}{l}\text { cases, } 3,431 \\
\text { control }\end{array}$ & & & & & $\begin{array}{l}\text { smoking, } \\
\text { diabetes, } \\
\text { HT treat- } \\
\text { ment, and } \\
\text { total cho- } \\
\text { lesterol). } \\
\text { Athero- } \\
\text { sclerosis }\end{array}$ & & $\begin{array}{l}5.1 \% \text { compared with con- } \\
\text { trols }(95 \% \mathrm{Cl}, \\
2.08 \%-8.11 \%) \text {. A meta-ana- } \\
\text { lysis of the effects of period- } \\
\text { ontal treatment on FMD } \\
\text { showed a mean improve- } \\
\text { ment of } 6.64 \% \text { between test } \\
\text { and control (95\% Cl, } \\
2.83 \%-10.44 \%) \text {. Periodont- } \\
\text { al disease is associated with } \\
\text { greater subclinical athero- } \\
\text { sclerosis as assessed by in- } \\
\text { creased c-IMT and an inde- } \\
\text { pendent predictor of cardi- } \\
\text { ovascular events in high-risk } \\
\text { populations. There is evid- } \\
\text { ence of an impaired FMD, } \\
\text { which is restored by period- } \\
\text { ontal treatment in individu- } \\
\text { als having periodontal dis- } \\
\text { ease. }\end{array}$ \\
\hline $\begin{array}{l}\text { Sanchez } \\
\text { et al } \\
(2017) \\
(42)\end{array}$ & NA & $\begin{array}{l}3 \mathrm{MA} / \mathrm{SR} \text { of } \\
\text { RCT, } 1 \mathrm{MA} / \\
\text { SR of RCT } \\
\text { and single } \\
\text { cohort stud- } \\
\text { ies, } 1 \text { SR of } \\
\text { oral health } \\
\text { promotion in- } \\
\text { terventions, } \\
\text { 1x SR of } \\
\text { RCT/quasi- } \\
\text { RCT, 1 MA/ } \\
\text { SR, } 1 \text { MA/SR } \\
\text { of interven- } \\
\text { tion trials, } 1 \\
\text { MA of pilot } \\
\text { trials, } 1 \mathrm{MA} / \\
\text { SR of inter- } \\
\text { vention and } \\
\text { noninterven- } \\
\text { tion trials, SR } \\
\text { of interven- } \\
\text { tion trials; } 2 \\
\text { SR, } 1 \text { LR, 1x } \\
\text { pre-post } \\
\text { mixed design, } \\
1 \text { pilot of an }\end{array}$ & $\begin{array}{l}34 \text { Studies in- } \\
\text { cluded from } \\
\text { Australia, } \\
\text { Europe, United } \\
\text { States, France, } \\
\text { Italy, United } \\
\text { Kingdom, Tur- } \\
\text { key, Sweden, } \\
\text { England }\end{array}$ & CVD & $\begin{array}{l}\text { Periodont- } \\
\text { al disease }\end{array}$ & $\begin{array}{l}\text { Periodont- } \\
\text { al treat- } \\
\text { ment }\end{array}$ & CVD & NA & AMSTAR & $\begin{array}{l}\text { Strong association between } \\
\text { periodontal disease and } \\
\text { CVD. Although a causal link } \\
\text { has not been confirmed } \\
\text { between periodontal dis- } \\
\text { ease and CVD, the general } \\
\text { consensus is that cardiovas- } \\
\text { cular patients need to be } \\
\text { made aware of this associ- } \\
\text { ation and its potential im- } \\
\text { plications. }\end{array}$ \\
\hline
\end{tabular}

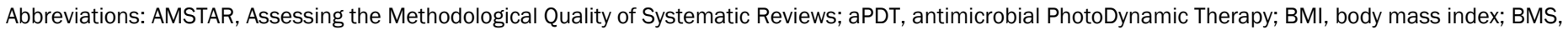

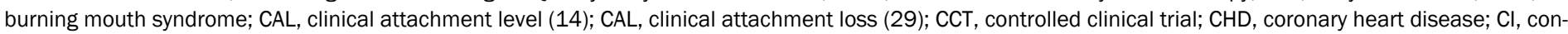

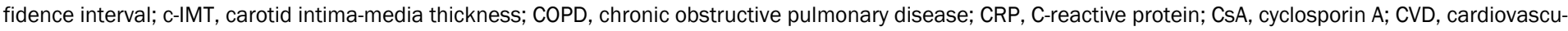

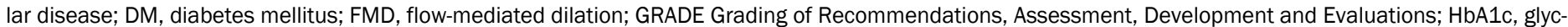

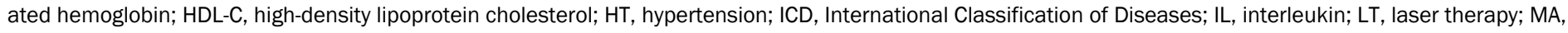

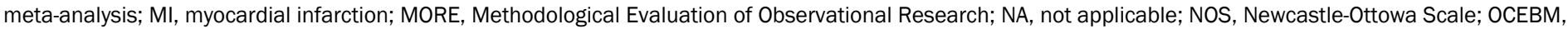

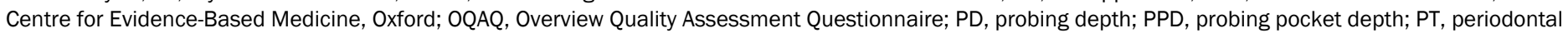

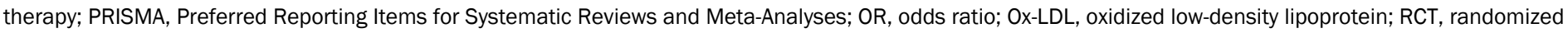

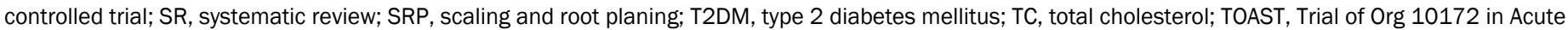
Stroke Treatment; WBC, white blood cell. 
(continued)

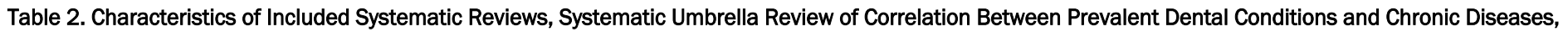
1995-2017

\begin{tabular}{|c|c|c|c|c|c|c|c|c|c|c|}
\hline Study & $\begin{array}{c}\text { Years } \\
\text { Searched }\end{array}$ & $\begin{array}{l}\text { Study } \\
\text { Type(s) }\end{array}$ & Population & $\begin{array}{l}\text { Chronic } \\
\text { Systemic } \\
\text { Disease }\end{array}$ & $\begin{array}{l}\text { Dental } \\
\text { Disease }\end{array}$ & $\begin{array}{l}\text { Interven- } \\
\text { tions }\end{array}$ & Outcome & $\begin{array}{l}\text { Common } \\
\text { Risk } \\
\text { Factors/ } \\
\text { Con- } \\
\text { founders }\end{array}$ & $\begin{array}{l}\text { Quality } \\
\text { Assess- } \\
\text { ment Tool } \\
\text { Used }\end{array}$ & Conclusions \\
\hline & & $\begin{array}{l}\text { oral health } \\
\text { program, } 1 \\
\text { oral health } \\
\text { guidelines for } \\
\text { prenatal } \\
\text { care, 1x best } \\
\text { practice re- } \\
\text { commenda- } \\
\text { tions; } 1 \text { RCT, } \\
1 \text { pre-post } \\
\text { test design, } 1 \\
\text { pilot of an } \\
\text { education } \\
\text { program, } 1 \\
\text { pre-post } \\
\text { mixed design, } \\
1 \text { pilot of an } \\
\text { oral health } \\
\text { education } \\
\text { model, } 2 \\
\text { cross-section- } \\
\text { al studies, } 3 \\
\text { pilots of a } \\
\text { screening } \\
\text { tool, } 1 \text { best } \\
\text { practice re- } \\
\text { commenda- } \\
\text { tions }\end{array}$ & & & & & & & & \\
\hline $\begin{array}{l}\text { Schmitt et } \\
\text { al }(2015) \\
(43)\end{array}$ & $\begin{array}{l}\text { Up to } \\
\text { Septem- } \\
\text { ber } 2014\end{array}$ & $\begin{array}{l}\text { RCTs: case- } \\
\text { control stud- } \\
\text { ies, cross- } \\
\text { sectional } \\
\text { studies, pro- } \\
\text { spective co- } \\
\text { hort pilot } \\
\text { study }\end{array}$ & $\begin{array}{l}\text { Studies in- } \\
\text { cluded in qual- } \\
\text { itative synthes- } \\
\text { is = 10; stud- } \\
\text { ies included in } \\
\text { quantitative } \\
\text { synthesis =7; } \\
\text { sample size in } \\
\text { total } 2,257 \\
\text { (range, } \\
26-814)\end{array}$ & $\begin{array}{l}\text { Arterial } \\
\text { stiffness }\end{array}$ & $\begin{array}{l}\text { Periodont- } \\
\text { itis }\end{array}$ & $\begin{array}{l}\text { Periodont- } \\
\text { al treat- } \\
\text { ment }\end{array}$ & $\begin{array}{l}\text { Primary out- } \\
\text { come had to be } \\
\text { the measure of } \\
\text { arterial stiff- } \\
\text { ness by means } \\
\text { of pulse wave } \\
\text { velocity assess- } \\
\text { ment. }\end{array}$ & $\begin{array}{l}\text { Age, sex, } \\
\text { smoking, } \\
\text { or diabetes }\end{array}$ & $\begin{array}{l}\text { GRADE } \\
\text { system }\end{array}$ & $\begin{array}{l}\text { The present systematic re- } \\
\text { view and meta-analysis sup- } \\
\text { port an association between } \\
\text { severe periodontitis and in- } \\
\text { creased pulse wave velocity. } \\
\text { The measurement of arteri- } \\
\text { al stiffness provides a cardi- } \\
\text { ovascular marker of the cu- } \\
\text { mulative impact of both } \\
\text { known and unknown risk } \\
\text { factors, which may include } \\
\text { periodontitis. }\end{array}$ \\
\hline $\begin{array}{l}\text { Teeuw et } \\
\text { al }(2014) \\
(44)\end{array}$ & $\begin{array}{l}\text { Up to June } \\
2013\end{array}$ & RCTs, CCTs & $\begin{array}{l}\text { Studies in- } \\
\text { cluded } n=20 ; \\
\text { cases in total } n \\
=865 \\
(11-212 \text { pa- } \\
\text { tients per } \\
\text { study)/control }\end{array}$ & $\begin{array}{l}\text { Athero- } \\
\text { sclerosis }\end{array}$ & $\begin{array}{l}\text { Periodont- } \\
\text { itis }\end{array}$ & $\begin{array}{l}\text { Treatment } \\
\text { of period- } \\
\text { ontitis }\end{array}$ & $\begin{array}{l}\text { Clinical CVD } \\
\text { parameters (ie, } \\
\text { clinical event, } \\
\text { such as angina } \\
\text { pectoris, MI, } \\
\text { stroke, death) } \\
\text { and/or mark- }\end{array}$ & $\begin{array}{l}\text { Over- } \\
\text { weight and } \\
\text { smoking }\end{array}$ & GRADE & $\begin{array}{l}\text { PT reduces the risk for CVD } \\
\text { by improving plasma levels } \\
\text { of inflammatory (CRP, IL-6, } \\
\text { TNF-a), thrombotic (fibrino- } \\
\text { gen), and metabolic (trigly- } \\
\text { cerides, TC, HDL-C, HbA1c) } \\
\text { markers and endothelial }\end{array}$ \\
\hline
\end{tabular}

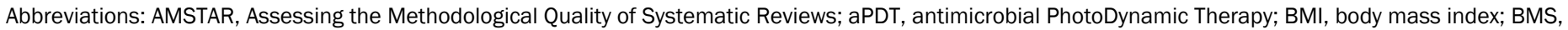

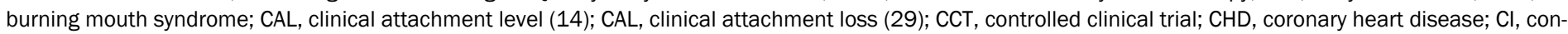

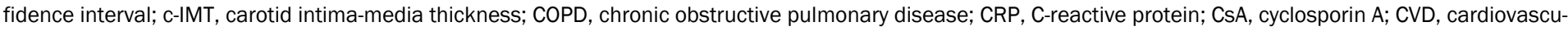

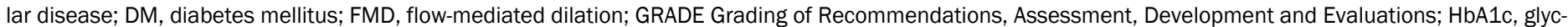

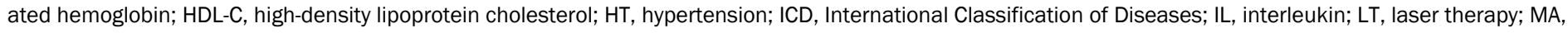

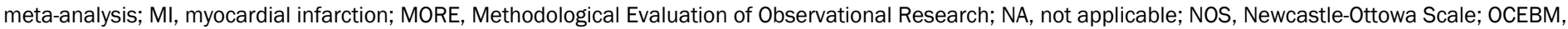

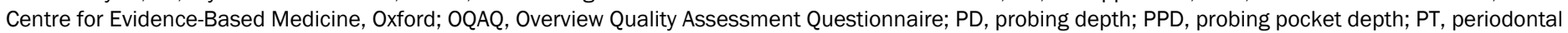

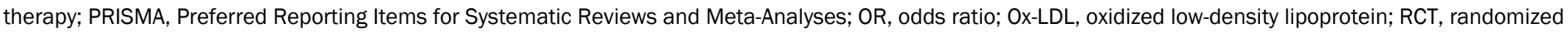

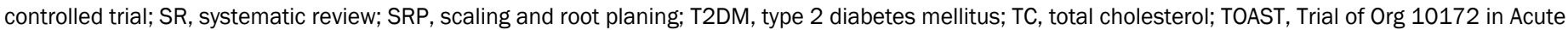
Stroke Treatment; WBC, white blood cell.

(continued on next page)

The opinions expressed by authors contributing to this journal do not necessarily reflect the opinions of the U.S. Department of Health and Human Services, the Public Health Service, the Centers for Disease Control and Prevention, or the authors' affiliated institutions. 
(continued)

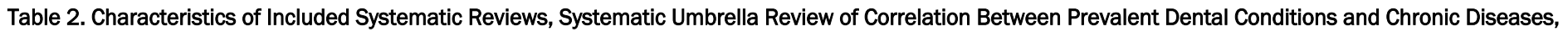
1995-2017

\begin{tabular}{|c|c|c|c|c|c|c|c|c|c|c|}
\hline Study & $\begin{array}{l}\text { Years } \\
\text { Searched }\end{array}$ & $\begin{array}{l}\text { Study } \\
\text { Type(s) }\end{array}$ & Population & $\begin{array}{l}\text { Chronic } \\
\text { Systemic } \\
\text { Disease }\end{array}$ & $\begin{array}{l}\text { Dental } \\
\text { Disease }\end{array}$ & $\begin{array}{l}\text { Interven- } \\
\text { tions }\end{array}$ & Outcome & $\begin{array}{l}\text { Common } \\
\text { Risk } \\
\text { Factors/ } \\
\text { Con- } \\
\text { founders }\end{array}$ & $\begin{array}{l}\text { Quality } \\
\text { Assess- } \\
\text { ment Tool } \\
\text { Used }\end{array}$ & Conclusions \\
\hline & & & $\begin{array}{l}\text { in total } n= \\
657(11-105 \\
\text { patients per } \\
\text { study). Cases } \\
\text { and control in } \\
\text { total } n=1522 .\end{array}$ & & & & $\begin{array}{l}\text { ers related to } \\
\text { atherosclero- } \\
\text { sis and CVD } \\
\text { risk, including } \\
\text { markers of sys- } \\
\text { temic inflam- } \\
\text { mation and } \\
\text { thrombosis, lip- } \\
\text { id and glucose } \\
\text { metabolism, } \\
\text { and vascular } \\
\text { function. }\end{array}$ & & & $\begin{array}{l}\text { function. This improvement } \\
\text { is sustained well more than } \\
6 \text { months after therapy, and } \\
\text { it is greater in those indi- } \\
\text { viduals having both period- } \\
\text { ontitis and co-morbidities } \\
\text { like CVD and/or DM. Our } \\
\text { findings emphasize the ef- } \\
\text { fectiveness and need for } \\
\text { periodontal diagnosis and } \\
\text { periodontal therapy in ather- } \\
\text { osclerotic and diabetic indi- } \\
\text { viduals to improve their sys- } \\
\text { temic health. }\end{array}$ \\
\hline $\begin{array}{l}\text { Tonsekar } \\
\text { et al } \\
(2017) \\
(45)\end{array}$ & $\begin{array}{l}\text { Up to April } \\
2016\end{array}$ & $\begin{array}{l}4 x \text { retrospect- } \\
\text { ive cohort, } 3 x \\
\text { prospective } \\
\text { cohort, } 1 x \\
\text { case-control } \\
\text { study nested } \\
\text { in a longitud- } \\
\text { inal study }\end{array}$ & $\begin{array}{l}\text { Studies in- } \\
\text { cluded } n=8 ; \\
4,075 \text { parti- } \\
\text { cipants; num- } \\
\text { ber of parti- } \\
\text { cipants } 144 \text { to } \\
911 ; \text { countries: } \\
\text { United States, } \\
\text { South Korea, } \\
\text { France, } \\
\text { Sweden. }\end{array}$ & Dementia & $\begin{array}{l}\text { Periodont- } \\
\text { al disease, } \\
\text { tooth loss }\end{array}$ & NA & $\begin{array}{l}\text { Outcome } \\
\text { measured was } \\
\text { assessed by } \\
\text { verified cognit- } \\
\text { ive tests such } \\
\text { as Mini-Mental } \\
\text { State Examina- } \\
\text { tion: Delayed } \\
\text { Word Recall } \\
\text { and Digit Sym- } \\
\text { bol Substitu- } \\
\text { tion Test. }\end{array}$ & $\begin{array}{l}\text { Apolipopro- } \\
\text { tein E } \\
\text { (ApoE) al- } \\
\text { lele, con- } \\
\text { sidered a } \\
\text { major ge- } \\
\text { netic risk } \\
\text { factor for } \\
\text { Alzheimer } \\
\text { disease } \\
\text { and a pos- } \\
\text { sible con- } \\
\text { founding } \\
\text { factor in } \\
\text { the associ- } \\
\text { ation } \\
\text { between } \\
\text { periodont- } \\
\text { itis and de- } \\
\text { mentia. }\end{array}$ & $\begin{array}{l}\text { Newcastle- } \\
\text { Ottawa } \\
\text { Scale } \\
\\
\\
\end{array}$ & $\begin{array}{l}\text { Association between sub- } \\
\text { sequent dementia, period- } \\
\text { ontal disease and tooth loss } \\
\text { was inconclusive. }\end{array}$ \\
\hline $\begin{array}{l}\text { Ung- } \\
\text { prasert et } \\
\text { al (2017) } \\
(46)\end{array}$ & $\begin{array}{l}\text { Up to July } \\
2016\end{array}$ & $\begin{array}{l}\text { Case-control } \\
\text { or cohort } \\
\text { study }\end{array}$ & $\begin{array}{l}\text { Studies in- } \\
\text { cluded } n=5 ; \\
\text { number of sub- } \\
\text { jects (cases/ } \\
\text { comparators) } \\
\text { 1) } 115,365 / \\
115,365 ; 2 \text { ) } \\
1,358 / 70,020 ; \\
3 \text { ) } 100 / 100 ; 4 \text { ) } \\
50 / 121 ; 5) \\
60 / 45 \text {. The } 5 \\
\text { studies in- } \\
\text { cluded }\end{array}$ & Psoriasis & $\begin{array}{l}\text { Periodont- } \\
\text { itis }\end{array}$ & NA & $\begin{array}{l}\text { Periodontitis } \\
\text { and risk of } \\
\text { psoriasis }\end{array}$ & $\begin{array}{l}\text { Con- } \\
\text { founders: } \\
\text { smoking, } \\
\text { obesity, } \\
\text { and DM }\end{array}$ & $\begin{array}{l}\text { New- } \\
\text { castle-Ott- } \\
\text { awa qual- } \\
\text { ity assess- } \\
\text { ment scale }\end{array}$ & $\begin{array}{l}\text { Patients with periodontitis } \\
\text { have a significantly in- } \\
\text { creased risk of psoriasis. }\end{array}$ \\
\hline
\end{tabular}

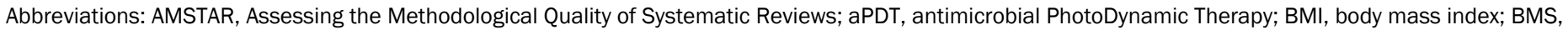

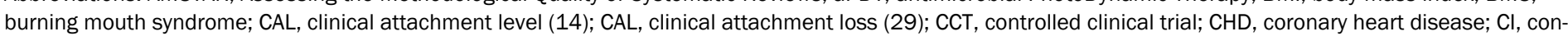

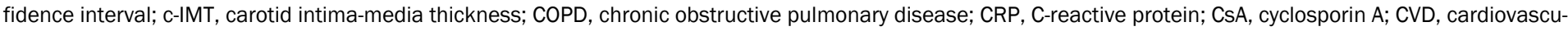

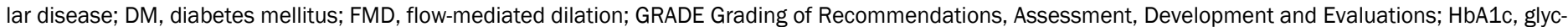

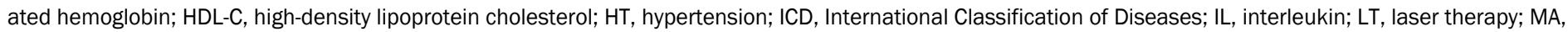

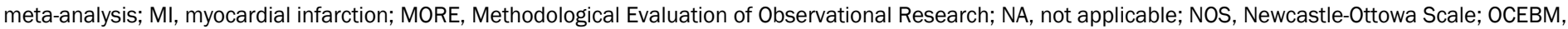

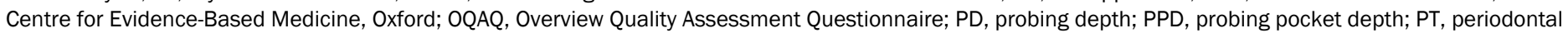

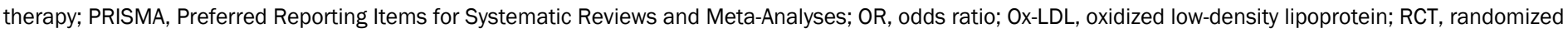

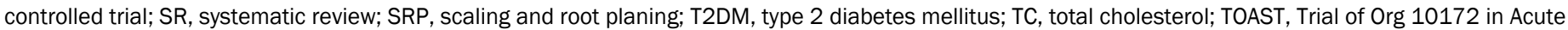
Stroke Treatment; WBC, white blood cell. 
(continued)

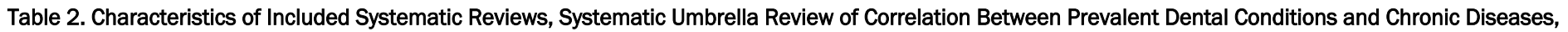
1995-2017

\begin{tabular}{|c|c|c|c|c|c|c|c|c|c|c|}
\hline Study & $\begin{array}{c}\text { Years } \\
\text { Searched }\end{array}$ & $\begin{array}{l}\text { Study } \\
\text { Type(s) }\end{array}$ & Population & $\begin{array}{l}\text { Chronic } \\
\text { Systemic } \\
\text { Disease }\end{array}$ & $\begin{array}{l}\text { Dental } \\
\text { Disease }\end{array}$ & $\begin{array}{l}\text { Interven- } \\
\text { tions }\end{array}$ & Outcome & $\begin{array}{c}\text { Common } \\
\text { Risk } \\
\text { Factors/ } \\
\text { Con- } \\
\text { founders }\end{array}$ & $\begin{array}{l}\text { Quality } \\
\text { Assess- } \\
\text { ment Tool } \\
\text { Used }\end{array}$ & Conclusions \\
\hline & & & $\begin{array}{l}312,584 \text { sub- } \\
\text { jects. Coun- } \\
\text { tries: Taiwan, } \\
\text { United States, } \\
\text { Greece, Nor- } \\
\text { way, Italy. }\end{array}$ & & & & & & & \\
\hline $\begin{array}{l}\text { Xu et al } \\
(2017) \\
(47)\end{array}$ & $\begin{array}{l}\text { Up to July } \\
2016\end{array}$ & $\begin{array}{l}6 x \text { cross-sec- } \\
\text { tional, } 12 x \\
\text { case control, } \\
4 x \text { cohort } \\
\text { studies }\end{array}$ & $\begin{array}{l}\text { Studies in- } \\
\text { cluded n = 22; } \\
\text { 129,630 parti- } \\
\text { cipants; coun- } \\
\text { tries: United } \\
\text { States, } \\
\text { Sweden, Ja- } \\
\text { pan, India, } \\
\text { Spain, Iran, } \\
\text { China, Ger- } \\
\text { many, Greece. }\end{array}$ & MI & $\begin{array}{l}\text { Periodont- } \\
\text { al disease }\end{array}$ & NA & $\begin{array}{l}\text { Periodontal dis- } \\
\text { ease (includ- } \\
\text { ing pocket } \\
\text { probing depth, } \\
\text { attachment } \\
\text { loss, bleeding } \\
\text { on probing, } \\
\text { plaque index, } \\
\text { gingival index, } \\
\text { X-ray, and mi-- } \\
\text { crobiological } \\
\text { results) and } \\
\text { the risk of } \\
\text { myocardial in- } \\
\text { farction }\end{array}$ & $\begin{array}{l}\text { Risk } \\
\text { factors in- } \\
\text { cluding } \\
\text { age, } \\
\text { smoking, } \\
\text { and dia- } \\
\text { betes are } \\
\text { common in } \\
\text { both PD } \\
\text { and MI }\end{array}$ & $\begin{array}{l}\text { Newcastle- } \\
\text { Ottawa } \\
\text { Scale }\end{array}$ & $\begin{array}{l}\text { Significant association } \\
\text { between periodontal dis- } \\
\text { ease and MI. Subgroup ana- } \\
\text { lyses also confirmed the el- } \\
\text { evated risk for MI in period- } \\
\text { ontal disease subjects. }\end{array}$ \\
\hline $\begin{array}{l}\text { Zeng, } \\
\text { Leng et al } \\
(2016) \\
(48)\end{array}$ & $\begin{array}{l}\text { Up to Feb- } \\
\text { ruary } 20 \text {, } \\
2015\end{array}$ & $\begin{array}{l}\text { 10x cross- } \\
\text { sectional, } 5 x \\
\text { case control }\end{array}$ & $\begin{array}{l}\text { Studies in- } \\
\text { cluded } n=15 ; \\
17,330 \text { parti- } \\
\text { cipants; coun- } \\
\text { tries: United } \\
\text { States, } \\
\text { Sweden, Ger- } \\
\text { many, Austria, } \\
\text { Italy, Spain, Ja- } \\
\text { pan, Portugal, } \\
\text { Poland, South } \\
\text { Korea, China. }\end{array}$ & $\begin{array}{l}\text { Carotid } \\
\text { athero- } \\
\text { sclerosis }\end{array}$ & $\begin{array}{l}\text { Periodont- } \\
\text { al disease }\end{array}$ & NA & $\begin{array}{l}\text { Risk of carotid } \\
\text { atherosclero- } \\
\text { sis as dia- } \\
\text { gnosed by c- } \\
\text { IMT (by ultra- } \\
\text { sound) or ca- } \\
\text { rotid plaque } \\
\text { thickness (by } \\
\text { panoramic ra- } \\
\text { diographs) }\end{array}$ & $\begin{array}{l}\text { Common } \\
\text { risk factor: } \\
\text { smoking; } \\
\text { con- } \\
\text { founder: } \\
\text { DM }\end{array}$ & NA & $\begin{array}{l}\text { Periodontal disease was as- } \\
\text { sociated with carotid athero- } \\
\text { sclerosis, although avail- } \\
\text { able evidence is insufficient } \\
\text { to confirm the causal rela- } \\
\text { tionship of periodontal dis- } \\
\text { ease and carotid athero- } \\
\text { sclerosis. }\end{array}$ \\
\hline $\begin{array}{l}\text { Zeng et al } \\
(2012) \\
(49)\end{array}$ & $\begin{array}{l}\text { Up to Janu- } \\
\text { ary } 10 \\
2012\end{array}$ & $\begin{array}{l}\text { Observation- } \\
\text { al studies } \\
\text { (cross-sec- } \\
\text { tional, case- } \\
\text { control, or co- } \\
\text { hort design) }\end{array}$ & $\begin{array}{l}\text { Studies in- } \\
\text { cluded } n=14 ; \\
\text { subjects (case/ } \\
\text { control): } \\
\text { between 28/ } \\
30 \text { and } 810 / \\
12,982 . \text { Coun- } \\
\text { tries: United } \\
\text { States, Poland, } \\
\text { Norway, Iran, } \\
\text { China, India. }\end{array}$ & COPD & $\begin{array}{l}\text { Periodont- } \\
\text { al disease }\end{array}$ & NA & $\begin{array}{l}\text { Relationship } \\
\text { between PD } \\
\text { and COPD }\end{array}$ & NA & NA & $\begin{array}{l}\text { Periodontal disease signific- } \\
\text { antly increases the risk of } \\
\text { COPD, with the increase be- } \\
\text { ing likely independent of } \\
\text { conventional COPD risk } \\
\text { factors. Dental plaque that } \\
\text { contains bacteria may be re- } \\
\text { sponsible for COPD, there- } \\
\text { fore, good attention to teeth } \\
\text { brushing and general oral } \\
\text { hygiene care may reduce } \\
\text { the risk of COPD. }\end{array}$ \\
\hline Zeng, Xia & Up to June & Cohort and & Studies in- & Lung Can- & Periodont- & NA & Risk of lung & Smoking & NA & Periodontal disease is asso- \\
\hline
\end{tabular}

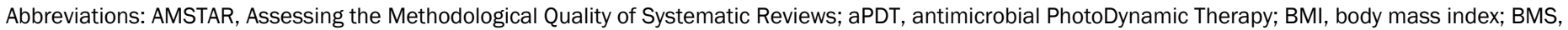

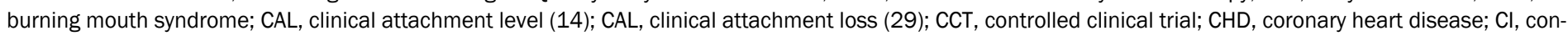

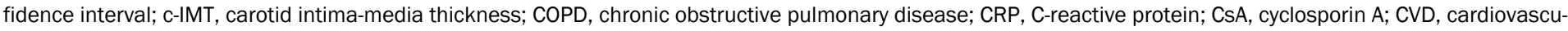

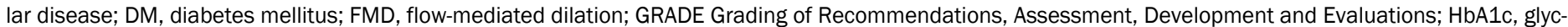

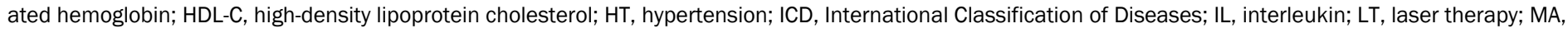

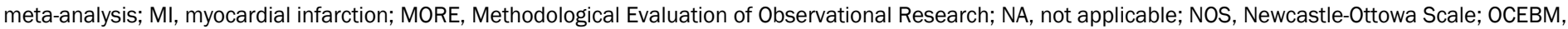

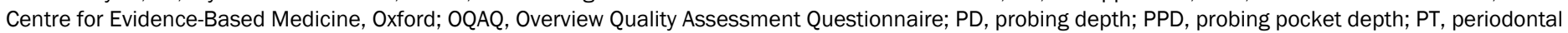

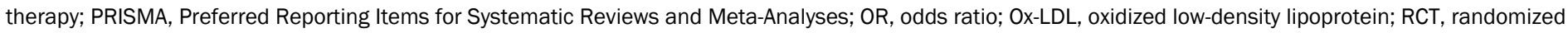

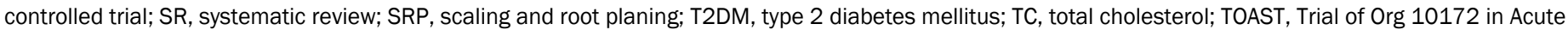
Stroke Treatment; WBC, white blood cell.

(continued on next page)

The opinions expressed by authors contributing to this journal do not necessarily reflect the opinions of the U.S. Department of Health and Human Services, the Public Health Service, the Centers for Disease Control and Prevention, or the authors' affiliated institutions. 
(continued)

Table 2. Characteristics of Included Systematic Reviews, Systematic Umbrella Review of Correlation Between Prevalent Dental Conditions and Chronic Diseases, 1995-2017

\begin{tabular}{|c|c|c|c|c|c|c|c|c|c|c|}
\hline Study & $\begin{array}{c}\text { Years } \\
\text { Searched }\end{array}$ & $\begin{array}{l}\text { Study } \\
\text { Type(s) }\end{array}$ & Population & $\begin{array}{l}\text { Chronic } \\
\text { Systemic } \\
\text { Disease }\end{array}$ & $\begin{array}{l}\text { Dental } \\
\text { Disease }\end{array}$ & $\begin{array}{l}\text { Interven- } \\
\text { tions }\end{array}$ & Outcome & $\begin{array}{l}\text { Common } \\
\text { Risk } \\
\text { Factors/ } \\
\text { Con- } \\
\text { founders }\end{array}$ & $\begin{array}{l}\text { Quality } \\
\text { Assess- } \\
\text { ment Tool } \\
\text { Used }\end{array}$ & Conclusions \\
\hline $\begin{array}{l}\text { et al } \\
(2016) \\
(50)\end{array}$ & 10,2015 & $\begin{array}{l}\text { nested case- } \\
\text { control stud- } \\
\text { ies }\end{array}$ & $\begin{array}{l}\text { cluded } n=5 ; \\
\text { subjects: (lung } \\
\text { cancer/ } \\
\text { sample): } \\
\text { 1)191/ } \\
\text { 11,328; } \\
\text { 2)236/ } \\
\text { 48,375; 3) } \\
\text { 225/30,666; } \\
\text { 4) 243/ } \\
\text { 153,566; 5) } \\
754 / 77,485 . \\
\text { Countries: } \\
\text { United States, } \\
\text { Sweden, } \\
\text { China. }\end{array}$ & cer & al disease & & $\begin{array}{l}\text { cancer in pa- } \\
\text { tients with peri- } \\
\text { odontal dis- } \\
\text { ease }\end{array}$ & & & $\begin{array}{l}\text { ciated with a significant and } \\
\text { increased risk of lung can- } \\
\text { cer. }\end{array}$ \\
\hline
\end{tabular}

Abbreviations: AMSTAR, Assessing the Methodological Quality of Systematic Reviews; aPDT, antimicrobial PhotoDynamic Therapy; BMI, body mass index; BMS, burning mouth syndrome; CAL, clinical attachment level (14); CAL, clinical attachment loss (29); CCT, controlled clinical trial; CHD, coronary heart disease; Cl, confidence interval; c-IMT, carotid intima-media thickness; COPD, chronic obstructive pulmonary disease; CRP, C-reactive protein; CsA, cyclosporin A; CVD, cardiovascular disease; DM, diabetes mellitus; FMD, flow-mediated dilation; GRADE Grading of Recommendations, Assessment, Development and Evaluations; HbA1c, glycated hemoglobin; HDL-C, high-density lipoprotein cholesterol; HT, hypertension; ICD, International Classification of Diseases; IL, interleukin; LT, Iaser therapy; MA, meta-analysis; MI, myocardial infarction; MORE, Methodological Evaluation of Observational Research; NA, not applicable; NOS, Newcastle-Ottowa Scale; OCEBM, Centre for Evidence-Based Medicine, Oxford; OQAQ, Overview Quality Assessment Questionnaire; PD, probing depth; PPD, probing pocket depth; PT, periodontal therapy; PRISMA, Preferred Reporting Items for Systematic Reviews and Meta-Analyses; OR, odds ratio; Ox-LDL, oxidized low-density lipoprotein; RCT, randomized controlled trial; SR, systematic review; SRP, scaling and root planing; T2DM, type 2 diabetes mellitus; TC, total cholesterol; TOAST, Trial of Org 10172 in Acute Stroke Treatment; WBC, white blood cell.

The opinions expressed by authors contributing to this journal do not necessarily reflect the opinions of the U.S. Department of Health and Human Services, the Public Health Service, the Centers for Disease Control and Prevention, or the authors' affiliated institutions. 
Table 3. Number of Systematic Reviews Observing Disease Correlations, Systematic Umbrella Review of Correlation Between Prevalent Dental Conditions and Chronic Diseases, 1995-2017

\begin{tabular}{|c|c|c|c|c|}
\hline Dental or Chronic Disease & Periodontitis & Tooth Loss & Dental Caries & \\
\hline Diabetes mellitus & $46(41 / 5)$ & $1(1 / 0)$ & $4(1 / 3)$ & 51 \\
\hline Cardiovascular disease & $33(22 / 11)$ & $6(6 / 0)$ & $2(1 / 1)$ & 41 \\
\hline Cerebrovascular disease & $4(0 / 4)$ & $2(0 / 2)$ & $2(0 / 2)$ & 8 \\
\hline Chronic obstructive pulmonary disease & $2(0 / 2)$ & $1(0 / 1)$ & - & 3 \\
\hline Dementia & $1(0 / 1)$ & $1(0 / 1)$ & - & 2 \\
\hline Psoriasis & $1(0 / 1)$ & - & - & 1 \\
\hline Lung cancer & $1(0 / 1)$ & - & - & 1 \\
\hline Total & 88 & 11 & 8 & 107 \\
\hline
\end{tabular}

Abbreviation: - , not applicable.

${ }^{a}$ The first number in the parentheses indicates the number of systematic reviews included in the umbrella review; the second number indicates the number of reviews that were individually included in the systematic reviews. 